WALDEN

UNIVERSITY

$A$ higher degree. A higher purpose.

Walden University ScholarWorks

Walden Dissertations and Doctoral Studies

Walden Dissertations and Doctoral Studies

Collection

2018

\title{
Domestic Terrorism in the United States
}

Joe B. Williams

Walden University

Follow this and additional works at: https://scholarworks.waldenu.edu/dissertations

Part of the Quantitative, Qualitative, Comparative, and Historical Methodologies Commons

This Dissertation is brought to you for free and open access by the Walden Dissertations and Doctoral Studies Collection at ScholarWorks. It has been accepted for inclusion in Walden Dissertations and Doctoral Studies by an authorized administrator of ScholarWorks. For more information, please contact ScholarWorks@waldenu.edu. 


\section{Walden University}

College of Social and Behavioral Sciences

This is to certify that the doctoral dissertation by

Joe Williams

has been found to be complete and satisfactory in all respects, and that any and all revisions required by the review committee have been made.

Review Committee

Dr. Lori Demeter, Committee Chairperson, Public Policy and Administration Faculty

Dr. Tamara Mouras, Committee Member, Public Policy and Administration Faculty

Dr. Eliesh Lane, University Reviewer, Public Policy and Administration Faculty

Chief Academic Officer

Eric Riedel, Ph.D.

Walden University

2018 


\author{
Abstract \\ Domestic Terrorism in the United States \\ by \\ Joe B. Williams \\ MS, Kaplan University, 2010 \\ BA, University of North Florida, 2008

\section{Dissertation Submitted in Partial Fulfillment \\ of the Requirements for the Degree of \\ Doctor of Philosophy} \\ Public Policy and Administration
}

Walden University

May 2018 


\begin{abstract}
Lone wolf terrorism has received considerable media attention, yet this phenomenon has not been sufficiently examined in an academic study. National security officials must distinguish between terrorist activities carried out by lone wolves and those carried out by terrorist networks for effective intervention and potential prevention. The purpose of this qualitative study was to explore the phenomenon of the leaderless lone wolf terrorist and the underlying mechanisms and processes that lead individuals to be drawn to or away from an existing radical movement. The theoretical framework for this study was leaderless resistance theory. Secondary data from interviews, field notes, and surveys from the RAND-MIPT Terrorism Knowledge Base and the Global Terrorism Database were analyzed using open and selective coding. Findings revealed 3 individual-level underlying mechanisms and processes (personal and political grievance, risk and status seeking, unfreezing) that lead individuals to be drawn to or away from an existing radical movement and to act unilaterally without direction toward violent ends. Findings also indicated that no single typology fits all perpetrators. The findings benefit national security officials and intelligence agencies by identifying lone wolf individuals, weighing the actual threat versus the perception, developing better counterterrorism strategies for the lone wolf phenomenon, and enhancing relations with outside agencies. Results may improve understanding of lone wolf terrorism and may be used to develop new policies to predict and track future threats.
\end{abstract}


Domestic Terrorism in the United States

by

Joe B. Williams

MS, Kaplan University, 2010

BA, University of North Florida, 2008

\author{
Dissertation Submitted in Partial Fulfillment \\ of the Requirements for the Degree of \\ Doctor of Philosophy \\ Public Policy and Administration
}

Walden University

May 2018 


\section{Dedication}

I would like to dedicate this dissertation to my daughter, Janiyah Williams; to my brother, James Rentz; and to parental figures, Dr. J. Stephen Waters and Shelley Waters. If it were not for them, I would not be where I am today, as they have encouraged me to soar to new heights. In addition, I would like to thank the rest of my friends and colleagues who have offered their support during this doctoral journey. Most importantly, I would like to dedicate this dissertation to God and my Lord and Savior Jesus Christ for giving me the strength, courage, and patience to continue throughout this doctoral journey. To God Almighty, I am forever indebted. 


\section{Acknowledgments}

I want to acknowledge and show appreciation to the faculty at Walden University, and friends who were of assistance in leading me in this direction of my academic career.

I would like to commend Dr. Demeter, my doctoral committee chairperson, who has assisted me in developing a quality research study. In addition, I would like to thank my committee member, Dr. Tamara A. Mouras, whose experience has proven to be invaluable in helping me complete this journey. 


\section{Table of Contents}

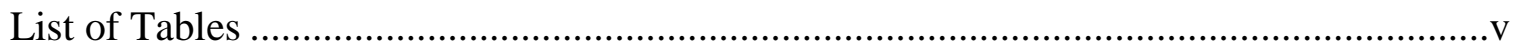

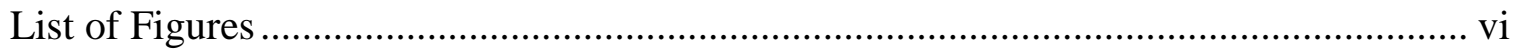

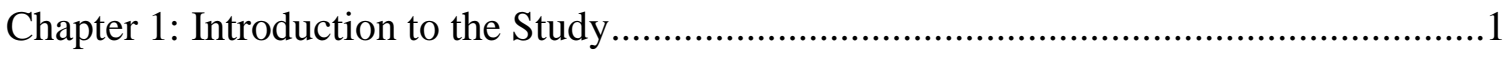

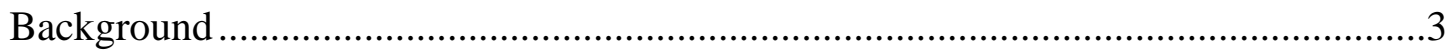

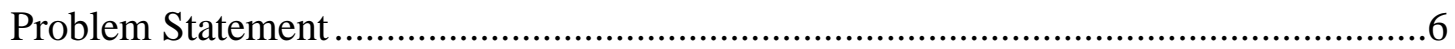

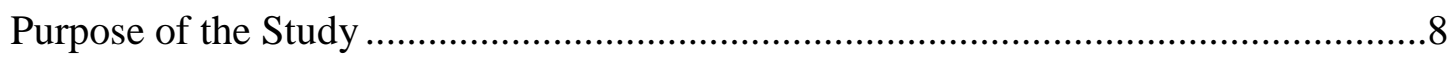

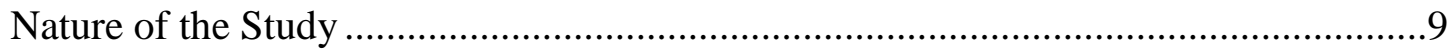

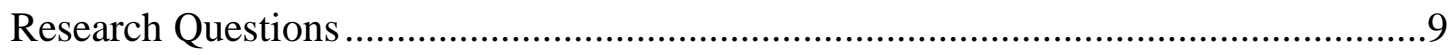

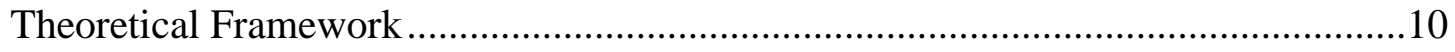

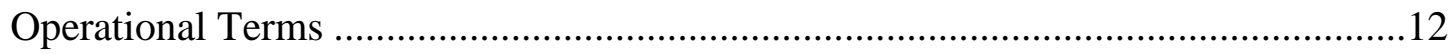

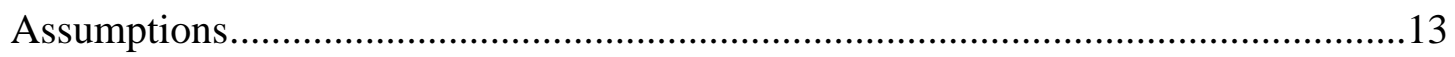

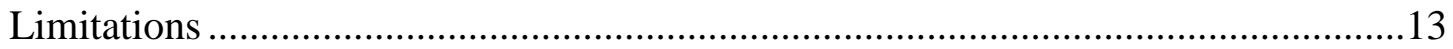

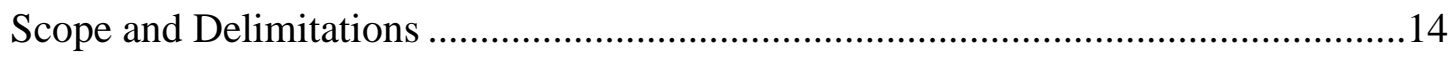

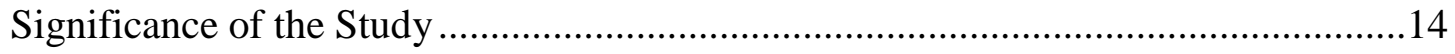

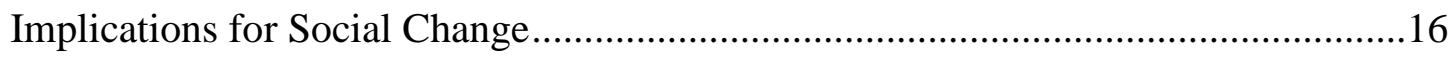

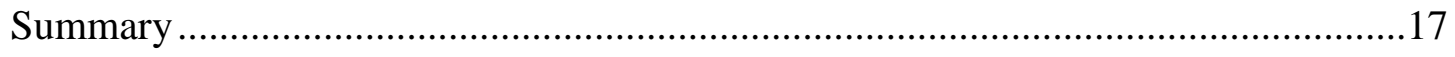

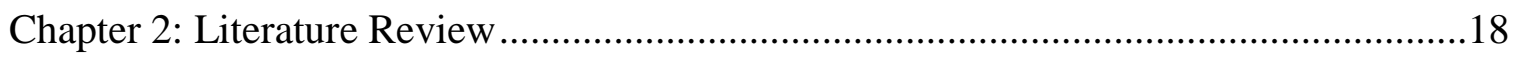

Lone Wolf: A Definition Melee....................................................................

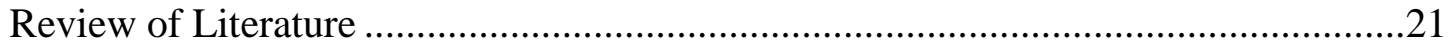

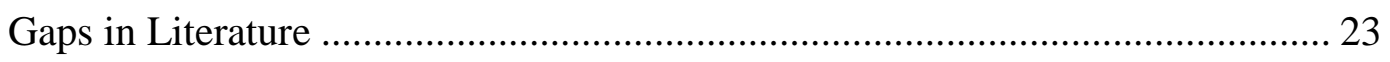

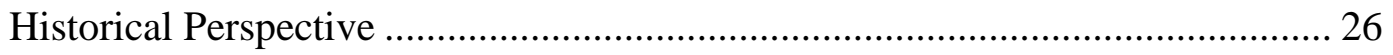


Research Strategy

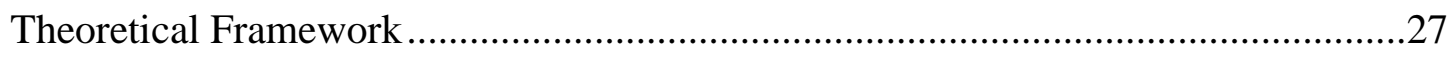

Leaderless Jihad: The Modern Face of Terror ...................................................... 31

Shift Toward Leaderless Resistance ….............................................................. 33

Lone Wolf: Characteristics, Psychological Factors, Risk Factors, and

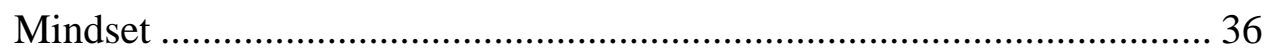

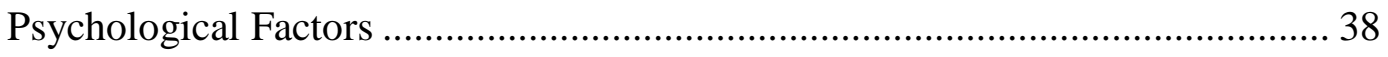

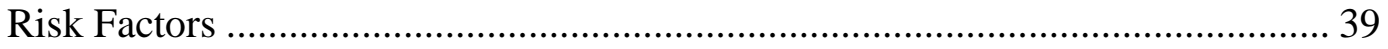

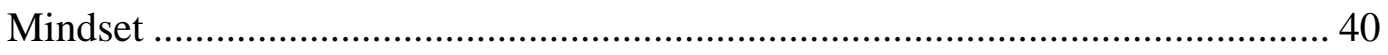

Lone Wolf: The Most Significant Threat to U.S. National Security ..................... 41

How the Theory Translates Into Practice............................................................ 45

Preventing Lone Wolf Terrorism..................................................................... 47

Social Change Mechanism......................................................................................49

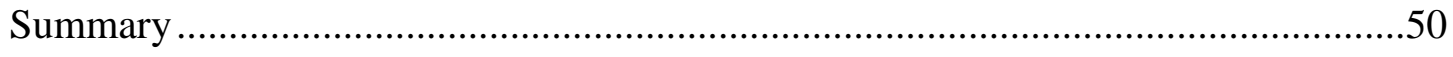

Chapter 3: Research Method.......................................................................................53

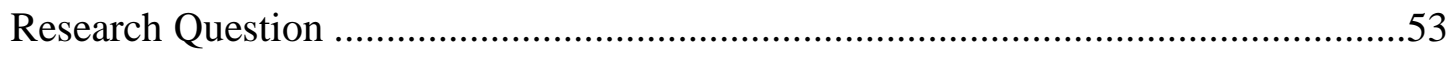

Research Design and Rationale ..............................................................................54

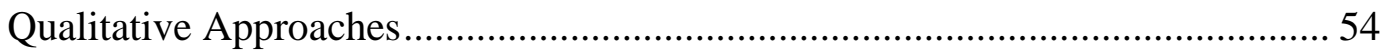

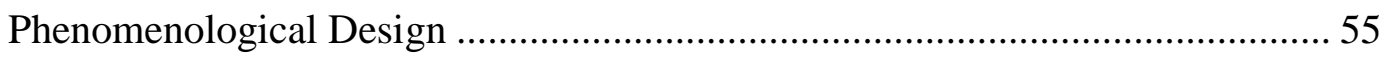

Secondary Data Selection Process ...........................................................................56

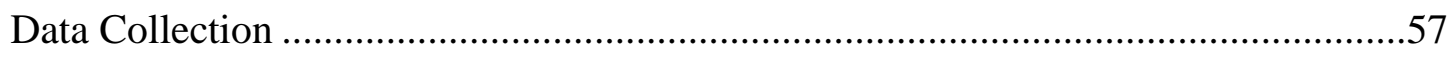

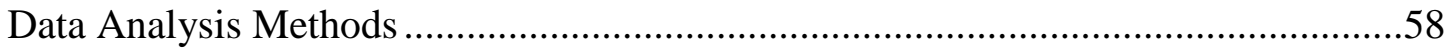


Ethical Issues in the Use of Secondary Data Analysis Research

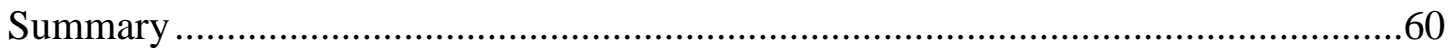

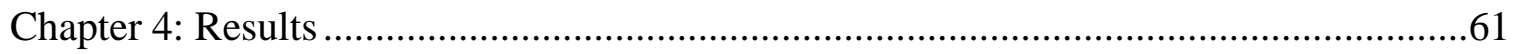

Central Research Question and Subquestions...................................................61

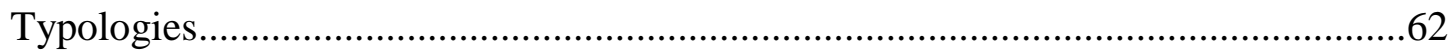

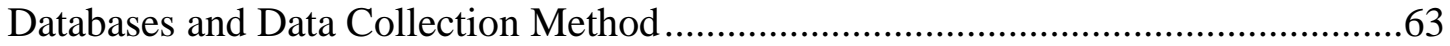

Codes 65

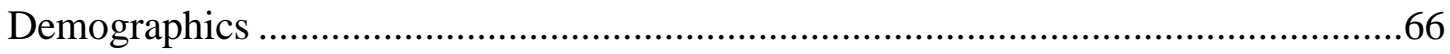

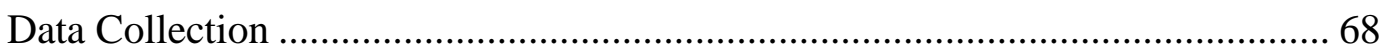

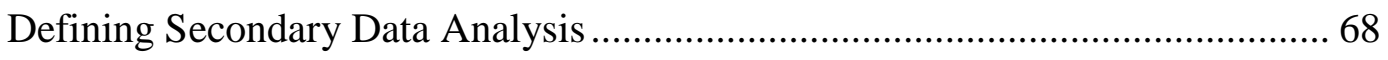

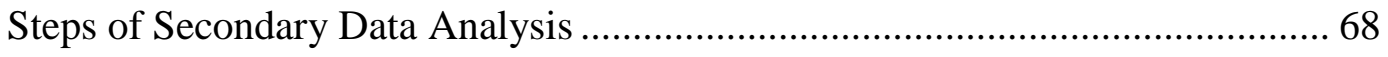

Data Analysis Process for Themes and Codes.....................................................69

Data Analysis Process for Excel Workbook ........................................................ 70

Results 71

Central Research Question.................................................................. 71

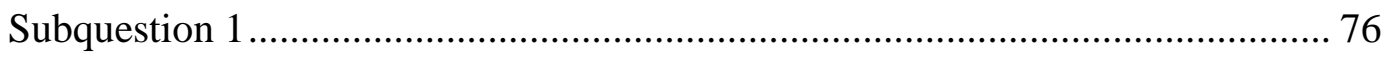

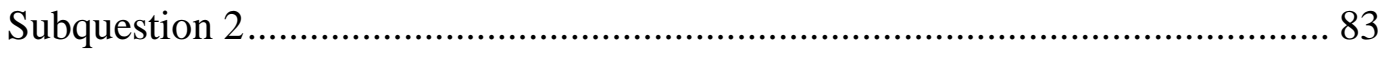

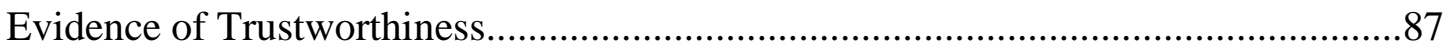

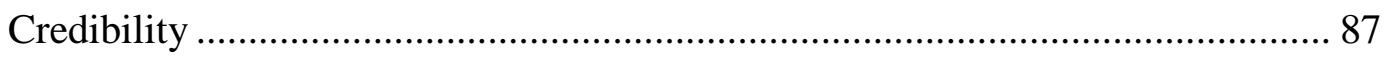

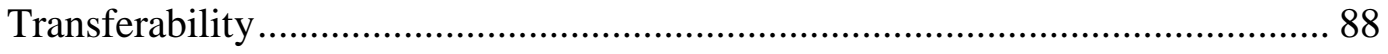

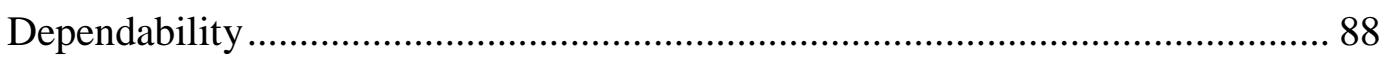

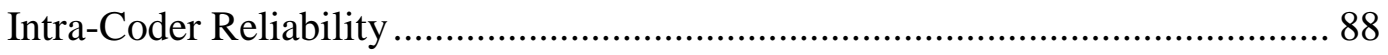

iii 
Summary

Chapter 5: Discussion, Conclusions, and Recommendations .............................................90

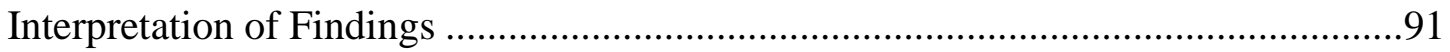

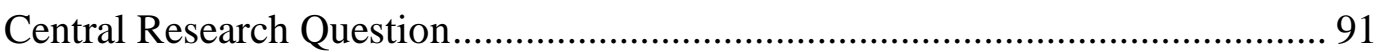

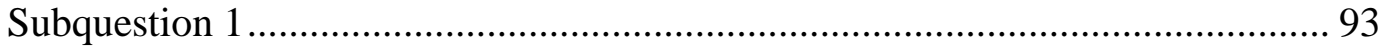

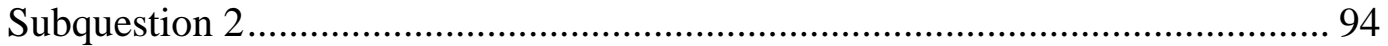

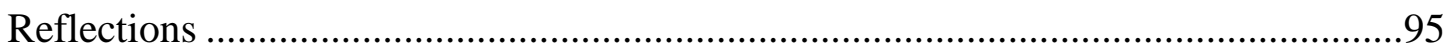

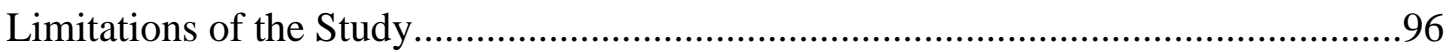

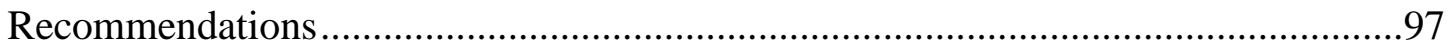

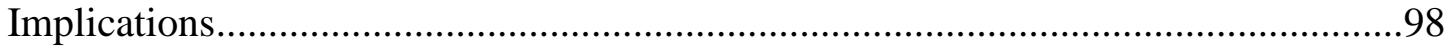

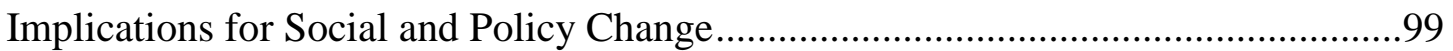

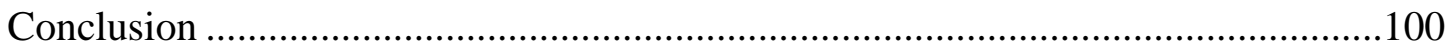

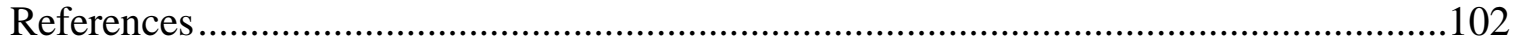

Appendix A: Central Research Question and Subquestions.........................................119

Appendix B: Terms and Defintions ........................................................................120

Identification- willingness of the attacker to commit violence as an agent of a

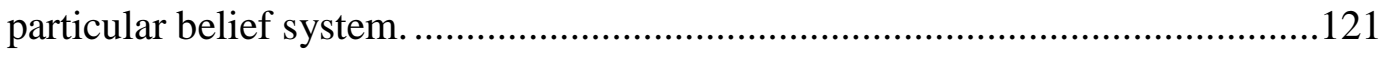

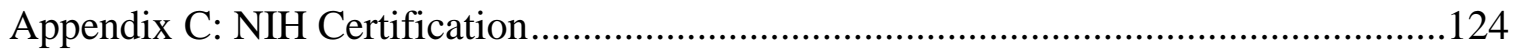

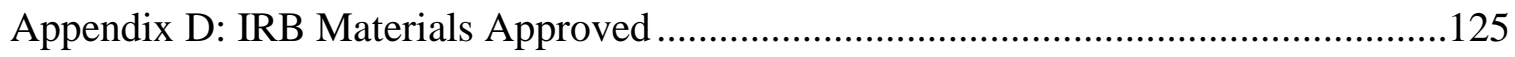




\section{List of Tables}

Table 1. Themes Derived from the Data Analysis of Lone Wolf Characteristics............37 


\section{List of Figures}

Figure 1. NVivo Text

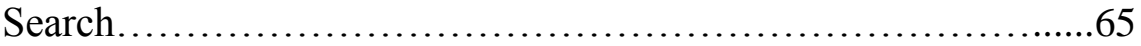

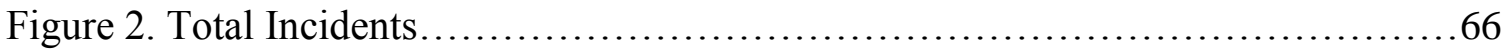

Figure 3. Basic Demographics of the Perpetrators....................................67

Figure 4. Nationality of Targets.....................................................

Figure 5. Mechanisms of Individual Radicalization...............................72

Figure 6. Right-Wing Ideology Extremist........................................77

Figure 7. Self-Developed Ideology Extremist....................................... 80

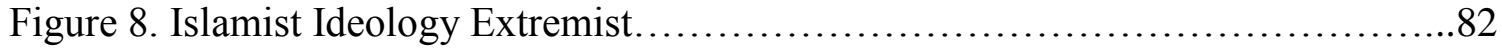

Figure 9. Indicators Characterizing the Lone Wolf...................................84 
Chapter 1: Introduction to the Study

Transnational Terrorism, Security, and the Rule of Law (TTSRL, 2013) stated that $80 \%$ of lone wolf terrorism attacks in the United States have come from within. According to TTSRL (2013), lone wolf terrorism is more widespread in the United States than in other countries, with U.S. attacks representing about $42 \%$ of all lone wolf attacks. National security officials must distinguish between terrorist activities carried out by lone wolves and those carried out by terrorist networks. Identifying these threats is imperative. Lieberman and Collins (2011) pointed out that the role of national security is to provide direct contact with other government agencies to thwart the attacks. Lone wolf terrorism is countered through examination of key trends, dimensions, and features. Examples of lone wolf attacks in the United States included the following:

- the 2013 bombing of the Boston marathon;

- the 2013 Navy Yard shooting in Maryland;

- the 2012 attempted suicide bombing of the U.S. Capital building;

- the 2011 shooting of an Arizona congresswoman and her supporters;

- the 2010 plane attack of an IRS building in Austin, Texas, by a tax protestor;

- the 2010 botched car bomb in New York Times Square attempting to blow up the subway system;

- the 2010 bomb plot in Dallas to blow up a former president's house;

- the 2009 shooting at Fort Hood by an army psychiatrist;

- the 2009 shooting at the Little Rock, Arkansas, Army recruiting center by an Islamic militant; and 
- the 2009 murder of a D.C. museum security officer by a man fascinated with Nazi Germany.

To prepare and protect the public, the U.S. government made modifications to Section 206 of the Foreign Intelligence Surveillance Act (FISA), known as the lone wolf provision (DeRosa, 2005). The modifications in Section 206 allowed the government to obtain judicial-instructed access to all things that are touchable, such as organizational files, in terrorist investigations. The stipulations increased access to documents that might be wanted and decreased the standard for a judicial official to give out a forceful command regarding their production (Lui, 2011). This modification was made because the behavior of a lone wolf terrorist is more difficult to detect apart from microcells (Lui, 2011). There are fewer opportunities for lone wolf terrorists to be caught because they act individually when planning the attacks, making it difficult for national security or law enforcement officials to trace them (International Association of Chiefs of Police [IACP], 2012). This is one of the reasons why national security officials and the intelligence community declared the lone wolf threat as one of the greatest to national security (IACP, 2012).

Many officials are concerned that something like 9/11 may occur again but on a larger scale. However, national security officials must also be concerned with smaller attacks by lone wolves (Carafano, 2011). National security officials must identify and thwart these attacks before they occur. However, if they do occur, officials must react quickly using coordinated efforts. One thing Congress can do is enhance reaction times; lone wolf terrorist attacks are ongoing, and national security must be ready at any 
moment (Carafano, 2011). Also, Congress must continue to update the U.S. Patriot Act because that might be the most efficient way to deal with the threat before it happens (Carafano, 2011). Finally, Congress should make sure that all government agencies are working together for information-sharing purposes and partnerships, as each unit plays an integral role in protecting the nation (Carafano, 2011). Although every attack cannot be thwarted, this approach may be Congress's best line of defense against terrorist attacks.

\section{Background}

The unique nature of these attacks requires lone wolves to act alone during an event, raising concerns among national security officials and citizens of the United States. Bergen and Hoffman (2010) stated that it is not costly for terrorists to carry out an attack. Carrying out an attack may cost only a few thousand dollars for an individual or microcell (Levitt, 2017). What is most frightening about this phenomenon is that it can be carried out swiftly, with minimum funding and preparation. (Bergen \& Hoffman, 2010). Terrorist threats are ongoing, especially toward the West, and U.S. national security officials must enhance all security measures to thwart attacks.

The capability among government agencies for sharing information and collaborating could enhance security measures when faced with a sudden attack. According to Bakker and DeGraaf (2011), counterterrorism operations need to be better equipped to detect lone wolf signals that indicate an individual's intent to carry out a terrorist attack. This requires efficient information collection and utilization throughout the information management process, which usually goes through the intelligence 
community production process. It also requires the intelligence community to work in partnerships with other agencies.

Research has shown that lone wolf attacks are often botched because of operational mistakes. Lone wolves follow a process and are vulnerable during the planning period. For example, U.S. Army Pfc. Naser Jason Abdon was arrested on suspicion after he planned to attack a store near the Fort Hood military base in Texas. The attack was thwarted because of several operational mistakes he made (Coffey 2011). Jose Pimentel, a natural U.S. citizen, was caught with improvised explosive devices he planned on using in New York. This attack was hindered due to Pimentel making himself vulnerable to detection by way of his Internet activities (Coffey, 2011). National security officials and other government agencies must detect these mishaps during the lone wolf's preparation phase and use every resource to capitalize on mistakes.

Studies have shown that terrorists often follow a model set by their predecessors. Lone terrorists' actions often mimic those of a group or individual, but they must improvise and/or scale down their method of attack because of unforeseen circumstances and conditions (Friedman, Harper, \& Preble, 2010). This is the strategy national security officials must exploit to detect patterns established by prior terrorists. As their method of attacks change and evolve due to unforeseen circumstances and conditions, national security officials must also adjust their method of detection (McClure, 2013). In 1994, intelligence efforts for security officials were revised in New York by Police Commissioner William Bratton. The revisions reduced violent and serious crime in New 
York by $80 \%$, and New York is now considered one of the safest large cities in the United States (Albrecht, 2011).

Revisions continue to have a significant impact, even with the additional counterterrorism methods that have been implemented since 9/11 (Albrecht, 2011). Tikuisis (2009) provided statistics on U.S. states that are prone to terrorist attacks. States that are smaller and weaker are more likely to experience violent terrorist attacks than stronger states by a 3:1 factor. This ratio increases to 5:1 when considering states' dislodgement of residents, individual protests, fiscal changes, and security mechanisms. Weaker states with moderate fiscal and social growth performances are more likely to experience terrorist attacks compared to other weaker states (Tikuisis, 2009).

National security relationships with other agencies play a significant role in filling the gaps to protect U.S. citizens. In principle, national security officials should refine their priorities and methods, share a collective vision between all agencies, define roles and duties within those agencies so communication is more effective, offer a rational model for congressional oversight, and communicate their intent to the people at home and overseas (Dale, 2013). Congress has carried out efforts, primarily through proceedings, to obtain a better understanding of the landscape of terrorism in many states and to measure the efforts of partnering agencies. Congress examined several platforms and procedures regarding national peacekeeping efforts; connections between transnational crime, drugs, and terrorism financing; and the link between homeland and transnational terrorism events (Painter, 2013). 
Miller (2013) stated that changes in the last decade have been messy and sparse; these changes have focused on an agency rather than the shared goal of all, and other changes should be made. U.S. national security agencies seem to be lacking the skills needed to communicate with others outside of their realm. Communication and sharing should be an essential function of national security, but this function seems to have been totally abandoned as reflected in sparse reforms (Miller, 2013).

The lone wolf threat is a concern to national security and the people of the United States. The modern security landscape requires a detailed and resolute approach to detecting and thwarting terrorist attacks (Valentin-Bogdan, 2013). This study provided a better understanding of the factors that influence lone wolf terrorists to act violently. The leaderless resistance model was the basis for examining the threat and dispelling the mystique. The model provided a theoretical approach to address concerns related to lone wolves.

\section{Problem Statement}

The problem addressed in this study was that lone wolf terrorism has received considerable media attention, yet this phenomenon has not been sufficiently examined in an academic study. FBI Director Robert Mueller (2003) reported that lone wolf terrorists are the most difficult to identify before they act, and therefore pose a huge security concern. Research regarding lone wolf terrorism has been limited (Arndt, 2011). Traditionally, terrorism has been examined as a group activity, and scholars have focused on group aspects and group socialization to explain individual pathways to terrorism (Spaaij, 2010). Early research on lone wolf terrorism came from creeds of anarchist, 
including a review of unexpectedly scarce theoretical writings on the topic in English (Feldman, 2013). The lone wolf problem was present 150 years ago, but now has become a ubiquitous feature of western political and counterterrorism dialogue in recent years. (Feldman, 2013). The lone wolf problem became evident when Theodore Kaczynski acted outside of an established terrorist hierarchy, killing three individuals and injuring 23 others (Phillips, 2011). Lone wolf terrorists have since been taking advantage of national security lapses. Although the Foreign Intelligence Surveillance Act included provisions to protect against lone wolf threats, there is a need to understand the underlying mechanisms and processes of the lone wolf. National security officials remain concerned about the endurance of established terrorist hierarchies, but new trends point to the increase of attacks by individuals and/or microcells who have very little, if any, contact with established terrorist hierarchies (Michael, 2012).

The lone wolf terrorist's ideology manifests in terrorist or radical actions. National security officials and the FBI are aware of these manifestations but will not formally list them as established terrorist hierarchies in the United States. Lone wolf terrorists include individuals who act on their beliefs to support animal rights, the environment, anarchism, White superiority, Black independence, anti-government, and abortion. Since $9 / 11$, lone wolf terrorists have been responsible for carrying out several dozen attacks, and there seems to be an increase in the number of hate groups present nationwide. Most of the hate groups' acts seem to be focused on the government (Bjelopera, 2012). A cohesive approach is needed to protect U.S. citizens (Dale, 2013). 
This problem is significant, and it invokes a sense of fear and dread. Lone wolf terrorists act alone and have no constraints regarding violence levels. They are unconcerned about what national security does before or after an attack, and prefer to isolate their supporters. When they act alone, they are much harder to detect because no other individual is aware of their intentions. Downing and Mayer (2013) asserted that lone wolves are more dangerous than established terrorist hierarchies. There have been at least 60 plots, 49 of which have been homegrown (Downing \& Mayer, 2013). Individuals or microcells are naturalized citizens, lawful permanent inhabitants, or guests.

The lack of cohesive communication among agencies has made it more difficult for national security officials to detect lone wolves. The minimal literature on the lone wolf phenomenon had made it difficult to understand the characteristics of lone wolves and how they translate ideology into practice. This qualitative study addressed this gap concerning lone wolves using secondary data analysis.

\section{Purpose of the Study}

The purpose of this study was to focus on the lone wolf phenomenon apart from other types of political violence and terrorism using the RAND-MIPT Terrorism Knowledge Base and the Global Terrorism Database. Using the leaderless resistance theory, this study was qualitative in nature and focused on the leaderless lone wolf terrorist phenomenon including the underlying mechanisms and processes that lead individuals to be drawn to or away from an existing radical movement and act unilaterally without direction toward violent ends. The literature provided insight into 
lone wolf terrorism and the changes that need to be made to address the security concern through secondary data analysis.

\section{Nature of the Study}

The qualitative method was used to assess the lack of understanding of the leaderless lone wolf terrorist phenomenon including the underlying mechanisms and

processes that lead individuals to be drawn to or away from an existing radical movement (TTSRL, 2008). Conducting qualitative research was a way to identify intangible factors, such as social norms, socioeconomic status, gender roles, ethnicity, and religion, whose role in the research may not be clear (see Creswell, 2009).

Research indicated that the process of self-radicalization of lone wolf terrorists remains misunderstood and warrants further scientific research (Christensen, 2004). Phillips (2011) discussed how understanding the individualistic nature of lone wolf terrorism might require more subtlety from several economic-theoretical models that may lend themselves to its analysis. Building on previous research, I used a qualitative phenomenological design to explore the threat of lone wolves. Lone wolves follow a pattern and are susceptible to exposure at some point in the process. Identifying this process was essential to addressing the problem posed by these individuals (Bjelopera, 2012).

\section{Research Questions}

There are two types of research questions: central questions and sub questions. Central questions are designed to explore the concept of the study or the central phenomenon. Sub questions separate the central question into a relevant question 
(Creswell, 2009). The central research question in this study was as follows: What are the underlying mechanisms and processes that lead individuals to be drawn to or away from an existing radical movement and to act unilaterally and without direction toward violent ends? The sub questions (SQs) for this study were as follows:

SQ1: What causes an individual to participate in lone wolf terrorism?

SQ2: Are there consistent and significant indicators that can characterize a potential lone wolf actor?

\section{Theoretical Framework}

The framework used to guide this study was the leaderless resistance theory. Essential to the leaderless resistance theory is the method of resistance that motivates individuals or microcells to undertake acts of political violence separate from an established hierarchy (Joosse, 2007). The relevance of this theory to this study was ideological inclusiveness that leaderless resistance advocates. Although leaderless resistance is used to avoid detection, ideological inclusiveness can be an advantage for individuals involved in groups, such as the Earth Liberation Front (ELF), because of what leaderless resistance advocates (Joosse, 2007).

According to Gruenewald, Chermak, and Freilich (2013), little is known about the nature of lone wolves and how everyone comes to this conclusion of violence. Once agencies understand lone wolves' characteristics and how they form their ideological mindset, they will be able to collaborate to develop solutions, such as detecting the threat and identifying individuals before their beliefs transforms into actions. 
Miller (2013) indicated that national security officials lack a cohesive tactical planning model. The model national security uses are somewhat outdated and is not an effective method of communication. Regarding national security, the intelligence community focuses on the overall issue of terrorism and takes a reactive approach instead of being proactive (Coaffee \& Rodgers, 2008). National security's structure and methods are more than 60 years old and are not relevant to address the most recent security concerns. The anxiety that U.S. citizens have been experiencing since $9 / 11$ is calling for a change in the system and communication methods of the national security apparatus (Miller, 2013).

Leaderless terrorists do not follow the traditional methods of an established terrorist hierarchy given the nature of their independence and fluid movements (Gray, 2013). The leaderless resistance theory assisted in exploring the motivational factors for ideological resistance by an individual rather than by leaders from an established terrorist hierarchy. This theory assumes that oppositional entities, such as the U.S. government, are problematic to individuals' survival, and therefore lone wolf terrorists use tactics to oppose the entities. Although the tactics of a lone wolf vary depending upon the circumstances and conditions, Dale (2013) indicated that leaderless resistance theory is suitable for examining the characteristics, ideology, and threats to national security of lone wolves in the United States. Leaderless resistance theory became important because lone wolf terrorists like Joseph Paul Franklin and Ted Kaczynski were very discreet and went years without being caught (Martinez, 2012). National security concerns are easier to comprehend using leaderless resistance theory, and the concerns regarding lone wolf 
terrorism in United States are better understood when considering the factors that make up the phenomenon.

\section{Operational Terms}

While conducting this research, I used many operational terms. The operational terms and theoretical meanings relevant to study ensue.

Established terrorist hierarchy: Terrorist covert groups that organize along similar lines of a terrorist organization (Anti-Defamation League, 2013).

FISA Act: "The Foreign Intelligence Surveillance Act of 1978 prescribes procedures for requesting judicial authorization for electronic surveillance and physical search of persons engaged in espionage or international terrorism against the United States on behalf of a foreign power" (Margulies, 2013, p. 7).

Leaderless resistance theory: Political Research Associates (2013) stated that leaderless resistance or phantom cells generally refer to spontaneous, autonomous, unconnected cells seeking to carry out acts of violence, sabotage, or terrorism against a government or occupying military force.

Lone wolf terrorist: Andrews (2009) states that a "lone wolf terrorist is a person who performs terrorism without direct orders or connections to any organization" (p. 1).

National security: National security is the obligation to preserve the survival of the country by way of financial control, mediation, and political command (Sitek, 2013).

Phenomenon: "A fact or situation that is observed to exist or happen, esp. one whose cause or explanation is in question" (Stampnitzky, 2013). 
RAND Terrorism Database: RAND Corporation has established and maintained a database of terrorism events dating back to 1968 , which contains comprehensive information on international and domestic terrorism. Initially, RAND collected lone incidents of international terrorism but started collecting and registering data on domestic terror attacks in 1998 (RAND Terrorism Database [RTD], 2013).

Self-radicalization: "A process by which an individual or group comes to adopt increasingly extreme political, social, or religious ideals and aspirations that (1) reject or undermine the status quo or reject and/or undermine contemporary ideas and expressions of freedom of choice" (FBI, 2013, p. 4).

\section{Assumptions}

There were four assumptions related to this study: (a) I assumed that reexamining existing data to understand findings from new perspectives would have value; (b) I also assumed that collecting data on lone wolf individuals from selected databases would require organizational approval due to sensitive information; (c) furthermore, I assumed that prioritizing a concept or issue that was relevant in the original data may not be relevant at the time of the current study; and (d) last, I assumed that the available data were collected openly and ethically.

\section{Limitations}

One limitation of this study was the term terrorism. Terrorism is subject to varying interpretations and perspectives: states, organizations, agencies, and individuals define the term differently. Further, the problem of terrorism as it exists today defies the 
boundaries of historical jurisdictions. Additionally, this study was limited by the challenges inherent in the reuse of qualitative data.

\section{Scope and Delimitations}

This study was limited to lone wolf terrorism in the United States. Lone wolf terrorism outside of the United States was not considered. The database searches were limited to acts of lone wolves. Group terrorism was not addressed in this study. The rationale for this choice was that lone wolves formulate individual methods and strategies that are different from those used in an established terrorist organization. Databases are ideal for researching lone wolf acts, and many can be found on administration websites. Due to challenges that arose when I conducted database searches, websites such as the Department of Homeland Security and search engines such as Google Scholar were used in the study.

\section{Significance of the Study}

The significance of lone wolf threats was addressed in recent studies (Spaaij, 2010). National security readiness enables agencies to collaborate to detect the lone wolf threat. Although there is no common vision among agencies regarding the concept of national security, many associates it with the Department of Homeland Security (DHS) and conventional military interaction (Dale, 2013). The purpose of the study was to examine the lone wolf phenomenon apart from other types of political violence and terrorism. The term lone wolf terrorism referred to terrorist activities carried out by individuals separate from those carried out by terrorist networks. Qualitative data were 
analyzed to identify the characteristics of lone wolf terrorists and formulate a base of knowledge for lone wolf terrorism.

Contributions to the base of knowledge included information addressing national security's concerns regarding terrorism threats and vulnerabilities. The exploratory research design allowed me to examine the lone wolf phenomenon separate from the group phenomenon. In addition, exploration of the psychological factors that influence the lone wolf to act violently could help the United States develop stronger security plans. According to the White House (2013), the President's top concerns are keeping Americans safe, making sure that U.S. values and ideas are preserved, securing the country against current threats, fending off terrorist attacks, and allocating more resources for stronger reaction and rebound capabilities.

Furthermore, the federal government and all other agencies should work together as close partners in a national approach. Brooks (2011) maintained that an enormous amount of work is required by Congress. The American people may need to be willing to pay for more security by giving up certain civil liberties.

Lone wolves are vulnerable to detection during the process of planning and executing the act. Many love wolves are unskilled and lack the knowledge, assets, and training necessary to carry out the violent act. Although the Internet is a guide for conducting attacks and making weapons, such as bombs, it cannot substitute for hands-on experience training in the real world. For these reasons, many lone wolves will at some point step out of their comfort zone (Bakker \& de Graaf, 2010) and be identified or 
arrested before they can conduct an attack. To deter lone wolf attacks, national security should take a collaborative approach:

National security officials and many other agencies across the federal government, local and private sectors, local communities across the nation, and overseas have worked hard since the $9 / 11$ attacks to make this country better and to alleviate and safeguard it against evolving threats, to lessen the risks, and expand the capacity to react and rebound from attacks. (DHS, 2013)

A determined effort is needed to secure the United States from lone wolf terrorism while protecting the basic liberties of citizens. Though threats remain, the United States is more powerful now than before $9 / 11$ and is better equipped to address evolving threats (DHS, 2013).

\section{Implications for Social Change}

There were four implications for social change because of this study. First, findings may be used to inform the people about decreasing recognition than increasing an environment of fear that threatens an aptitude of social cohesion. According to the Lammers and Hickson (2013), social cohesion and synchronization are necessary to hold people together in times of an emergency. A second implication for social change was to present data on how the lack of approach to reducing this threat sends a message that social cohesion is not important. A better understanding of lone wolf terrorism could help the American people work together to mitigate the threat. A third implication for social change was to improve communication about U.S. values. Fourth, reducing fear and uncertainty about national security was is valuable long-term implication for positive 
social change. All the above-mentioned implications should foster social change for national security and all intelligence agencies. The people of this nation can withstand great progress and advances in the ways national security services are supplied on top of improving national security reputation with all other agencies and the citizens of this country. Likewise, Americans may become more informed toward the existing situation and more doctrinally vested in the process.

\section{Summary}

The results of this qualitative secondary analysis study may improve understanding of lone wolves' characteristics. National security officials should adopt a more cohesive approach to engage with other agencies to develop strategies to address national security threats. Currently, the national security approach lacks cohesiveness and overlooks the responsiveness of other federal and local agencies during an emergency or terrorist attack. Changes to national security policy are needed to address the ongoing threats of lone wolf terrorism. Chapter 2 provides a review of literature pertaining to lone wolf terrorism, national security preparedness, and reasons why national security officials are concerned. 
Chapter 2: Literature Review

The leaderless resistance theory illustrated that there is a lack of cohesiveness in the national security approach, and national security officials and other government entities should collaborate to develop strategies to address the growing threat of lone wolf terrorism (Alexander, 2009). The U.S. media promotes lone wolf terrorism by stressing fear and uncertainty despite a lack of examination of the lone wolf phenomenon. The purpose of this study was to explore the phenomenon apart from other types of political violence and terrorism using the RAND-MIPT Terrorism Knowledge Base and the Global Terrorism Database. This chapter is organized according to the themes that emerged during the literature review. The themes in the literature search stemmed from the theoretical framework of understanding the imbalance of power that manifests in lone wolves surfacing as terrorists or radical extremists (Michael, 2012). The research provided evidence of post-9/11 lone wolf terrorism in the United States, and the purpose of this study was to enhance the U.S. national security approach to deal with the future threats and attacks.

This chapter starts with the definition of terrorism as an ongoing threat, followed by a review of existing literature and the gaps pertaining to lone wolf terrorism. The chapter also presents the leaderless resistance theory from the 1960s. In addition, I examine aspects of the phenomenon by assessing the practice, characteristics, and paradigm of the government's approach. A cohesive approach to national security is presented that may help thwart threats and attacks. Chapter 2 concludes with the social change mechanism concerning homeland terrorism. 


\section{Lone Wolf: A Definition Melee}

One issue when conducting research on the nature of this phenomenon was the lack of a consistent definition. Terrorism has been defined in many ways, and there has been no universal definition that all scholars have accepted. Government officials, scholars, and other stakeholders use the term terrorism to illustrate different types of violence, thereby diluting the meaning (Spencer, 2006).

Violent acts such as kidnapping, insurgent attacks, piracy, and guerilla warfare are considered terrorist attacks. However, there is uncertainty surrounding the multifaceted definition of terrorism, which is evident in the models used to detect it, and which is seen in the debates that take place in national security conferences (Rapin, 2011). If the United States and the international community could agree on a collective definition of terrorism, the exclusion clauses under the 1951 Geneva Convention would establish standards of international law comprising of terrorism (Simeon, 2010).

The lack of a clear definition of this phenomenon has prompted many debates. According to Smyth (2009), a taped conversation with Letta Tayler, senior researcher of Human Rights Watch, indicated that government authorities have largely contested views on terrorism because no one knows exactly what it really is, and it is broadly defined. When questioned about the impact and results of the war on terror, Tayler (as cited in Smyth, 2009) stated that terrorism undercuts regulations, customs, and communal safety.

Mazhar, Khan, and Goraya (2013) noted that terrorism can be defined as violent behavior that is motivated politically on behalf of individuals, groups, or states. The purpose of terrorism is to instill fear in the opposition and its population to influence 
decisions and change their behaviors. A collective definition of terrorism is essential to any real fight on terrorism. A neutral definition should be founded on established international regulations and doctrines pertaining to the behaviors that are allowed in conventional wars among states (Boaz, 2010). The issue of trying to define the term has had a philosophical predisposition in the continuing melee (Acharya, 2008).

More recently, Jackson (as cited in Stump, 2013) tried to rewrite the definition of terrorism, but not without major criticism. Critics pointed out that Jackson's attempt to redefine terrorism was expressed from a closed-minded perspective that limited the capacity to logically study terrorism (Althied, 2006). Second, critics believed Jackson considered terrorism a type of bizarre violence, which has led some researchers to prejudge the phenomenon and overlook relevant and prominent features of terrorism. Critics said the way Jackson approached terrorism was not sufficient for terrorism studies and did not provide a systematic structure for researchers studying terrorism (Stump, 2013).

No matter the circumstance or event, nations and governments define terrorism from the perspective of their organizations. The definition used by the U.S. government describes terrorism as "premeditated, politically motivated violence perpetrated against noncombatant targets by sub-national groups or clandestine agents" (CIA, 2013, p. 1). Based on this definition, the language involving terrorist attacks are very similar. The only differing factor involves the location of the attack, which can include international or domestic. The understanding of terrorism is difficult for reasons other than the 
definition. Since 9/11, characteristics of terrorism have changed. Studies have not only addressed the strategies, but have also addressed the characters involved (Gilly, 2013).

\section{Review of Literature}

The need to review the underlying mechanisms and processes that lead the lone wolf terrorist to be drawn to or away from an existing radical movement has far-reaching security concerns. The review of literature provided insight into lone wolf terrorism and the changes that need to be made to address the security concern. The DHS (2011) reported lone wolf terrorism to be the most prevalent threat domestically. In addition, Spaaij (2010) stated that the term lone wolf was given to White racists who used the tactic to bring about change. There is growing concern for national security to detect prospective terrorists and to prepare citizens from horrific terrorist events. National security officials should understand how these individuals think and operate to save lives and apprehend the individuals who may commit such acts. It is critical for the government and intelligence agencies to identify a pattern and expose lone wolf terrorists.

Bates (2012) stated that the consequence of being unprepared leads to casualties and property destruction, which poses a security concern. Although effective security measures are in place, the development of leaderless resistance methods and tactics are facilitated through the advancement of technology (Bates, 2012). Terrorism comes in different forms and structures and the lone wolf terrorist has formed a personal and political impasse. Domestically, radical extremists cause a challenging and urgent threat to U.S. national security. 
Lieberman and Collins (2011) assessed that the role of national security involves the Attorney General, the Director of National Intelligence, the Secretary of Homeland Security, and direct coordination from the federal and local governments. It is very important for agencies to coordinate and use proper training during the investigative process. Legal ethics training aims to elude any violations of human rights and decisions that otherwise may violent civil freedoms. (Bryneilson et al., 2013). Many factors are involved when an individual decides to act alone or be a part of an established terrorist hierarchy (Nijboer, 2012).

Stewart (2011) said it is very challenging to separate extremists who have every intention to commit terror acts oppose to those who just voice their opinion of hate. National security officials use unlimited resources and time searching for individuals who maybe transitioning their extreme beliefs into actions. This is a frightening assignment assuming the enormous number of potential suspects. Achieving this goal requires consistent engagement from communities and businesses, and it is important for everyone to do their part by reporting potential individuals to national security officials (Cooper, 2012).

Evidently, this has had some effect. The growing threats of lone wolf terrorism domestically has forced security officials to contend with the facts that radicalization develops here in the United States (Levitt, 2017). Barnes (2012) asserted that present security techniques focuses on the culpabilities and liabilities designed for group interactions, a deterrent method to terrorism that is unsuitable to the lone wolf terrorist. However, most lone wolves are unskilled and the act never fully develops. The same 
characteristics that make lone wolves difficult to apprehend also reduces the damage that can be done (Barnes, 2012).

Armed forces have minimized the terrorism threat from overseas (Barnes, 2012).

The homeland threat has come from unidentified individuals who use violence to express their beliefs and opinions. Recently, domestic terrorism effects had been felt on April 15, 2013, when brothers Dzhokhar and Tamerlan Tsarnaev dropped two pressure-cooker bombs near the finish line of the Boston marathon race, killing three and injuring an estimated 264 people. Over the past several years lone wolf terrorism has been the media's primary dialogue.

\section{Gaps in Literature}

The lone wolf threat has been always relevant, but the element of this

phenomenon has not been sufficiently examined. Academic scholars hypothesize whether the phrase has provoked a sense of fear and dread, and how much does the media contributes to a certain degree, based upon the threat of the mystique (Stewart, 2011). However, when looking at the lone wolf history, there is a significant gap between lone wolf theory and lone wolf practice. To put the lone wolf threat into the proper context, an assessment of this gap would be very helpful, and doing so would provide an understanding of the lone wolf phenomenon and their history (Stewart, 2011). The media must have a different approach to lone wolf terrorism when trying to dispel the mystique and address the problems lone wolves pose. Common sense and knowledge implies that accomplishing this objective is not simple. 
O’Donnell and Gray (2012) mentioned that terrorism expert Brian M. Jenkins expressed that "Terrorism is a Theatre," and that the media is its greatest resource and cause. When an attack or act occurs the media continuously show its viewers narrative scenes from the activity. Jenkins argued that this was witnessed twice throughout the world, during the 1972 Olympics and the September 11, 2001, attacks (O’Donnell \& Gray, 2012). The media can counter opposing terrorism methods by limiting the amount of coverage shown on terrorist activities. As technology has emerged, information via media outlets are accessible to almost anyone around the world.

Terrorist's propaganda and websites are being viewed on Face book, Twitter, and YouTube, to inform, discover, and interact with the potential lone wolf terrorists. The media, even after the September 11 attacks, caused confusion regarding the unsettling political situation surrounding Iran's nuclear plants and Edward Snowden's release of classified information (Greenwald, 2014). Though these are ongoing events, the media would be purposely driven, given their considered attention to the Middle East, to highlight the chaos characterized by religious clashes and democratic opposition.

People's reaction to the media coverage of terrorism varies, but it does have an everlasting effect on them. Shoshani and Slone (2008) did a study and assessed the reactions of 300 Israeli adults. The individuals were randomly chosen and they either watched terrorism or non-terrorism related media on television. What they found was that emotional and attitudinal reactions to terrorism in the media were a lot higher than those on the non-terrorism media viewers. These findings reveal how a considerable amount of 
media coverage can significantly affect an individual's emotional and attitudinal reactions through the persuasion of media (Shoshoni \& Slone, 2008).

Terrorist attacks get considerable media attention. Those that are specific and surprising, creating high levels of uncertainty and the perception of a severe threat, define disaster situations (Saunter \& Carafano, 2012). The September 11 terrorist attacks were clearly defined as a disaster, and people agree that it was one the most disastrous in modern U.S. history. It is important to understand the traumatic effect of these situations and how they can be prevented or reduced. The media has not realized how much lone wolf terrorists are counting on them, to lead their cause. The more the situation demands a question from memory, the more likely an inaccurate response will be made (Lindsay, 2011).

Michael (2013) noted that the Internet is prevalent and serves a variety of purposes. Those issues stem from social issues, emergencies, and or disastrous situations. Terrorist groups like Al-Qaeda use the Internet and other media outlets for propaganda reasons. Research shows both the positive and negative aspects of media related terrorism, yet, terrorist propaganda mirror the effect of the domestic self-radicalized lone wolf. This involves no communication or direct links to establish terrorist organizations, as well as taken advantage of the new media platform (Howie, 2012).

Guterman (2013) focused on terrorism and media but centered the approach on how Muslims are portrayed in the media. The media is very careful and maneuvers through dangerous grounds, to not cause further controversy, or use bias overtones regarding Muslim relations in this state, per Muslim Americans. Guterman, however, did 
not go into details of why they might feel that way and why some resents Americans, leading to an increase in lone wolf terrorism activities here in the states.

\section{Historical Perspective}

Lone wolf terrorism is not a new phenomenon. This is factual of modern terrorist acting like past anarchists and their extremist views and agendas. Individuals who expressed their radical beliefs and used violence as a result were likely motivated by mental distress and poverty (Kassel, 2009). In the beginning, terrorism was not a choice of violence. Terrorism came about because of stressful economic conditions, public fighting, and government suppression of diplomatic controlled practices and demonstrations, which led to the creation of anarchist motivation. This started a domino effect of social resentment, suppression, and retaliation. Although readings show a greater period where information could have been quantifiably examined, the trail of terrorist activities could be traced back from four decades (Rasler \& Thompson, 2009).

In the U.S. from about the 1960's and beyond, the leaderless resistance model was associated with White supremacists and people who were against the government. Political Research Associates (2013) associated the term "leaderless resistance" to impulsive, self-ruling, unknown, or identified individuals trying to commit acts of violence, or terrorism toward a government or government entity. The term is frequently credited to Louis Beam, an American white nationalist, but Beam gives praise to Ulius "Pete" Louis Amoss, a U.S. intelligence officer who wrote about leaderless resistance in 1953. The term is used in numerous of ways to refer to individuals or networks, which causes confusion. Comparatively, leaderless resistance was associated with individuals 
that engage with cells and lack the hierarchical command associations (Political Research Associates, 2013).

\section{Research Strategy}

The following databases were used in conducting the literature search: RAND Database of Worldwide Terrorism incidents (RDWTI), Post-9/11 Terrorism Database, Data Collections-Start-National Consortium for The Study of Terrorism and Responses to Terrorism, and ProQuest Dissertations \& Theses. Additional websites such as The Department of Homeland Security and Google Scholar was also used. The following keywords were asserted: terrorism, loner, lone wolf terrorism, lone wolf, lone wolf terrorist, domestic terrorism, terrorism threats, stray mutts, and self-radicals. Recommendations from the keyword articles led to discovering more resources. Those resources found was directly associated with lone wolf terrorists or lone wolf terrorism. This assessment highlighted lone wolf terrorism and their threats in the homeland.

\section{Theoretical Framework}

The leaderless resistance concept formed the theoretical base for setting aside the mystique of the lone wolf to examine the reality of the phenomenon. The concept offered a theoretical approach that personifies concerns related to lone wolves, which are those acting outside of known, identified and/or established leadership hierarchy. It focused on what causes individuals to unilaterally take violent actions in the name of a political or social cause. Similar studies used leaderless resistance as their framework to explain the phenomenon as a new strategy to show the diminishment of terrorist and insurgent movements internationally (Michael, 2012). This study focused on the phenomenon- 
distinguishing them from other types of violence and terrorism (Michael, 2012). The leaderless resistance concept is the idea strategy model of opposition and guide individuals or micro groups to fully participate unilaterally in any established leadership hierarchy. While leaderless resistance is used to shun detection, penetration, and trial by the state, the problem manifests and individuals become immune to counter-ideology (Joosse, 2007). It is when this process is identified that national security officials can collaborate and foster solutions on how to approach this growing threat. This is the point where all securing officials create a plan for lone wolf terrorism.

RAND Database of Worldwide Terrorism Incidents (RDWTI) was created as a project to tackle the most complex problems facing our nation, such as terrorism (RTD, 2013). The leaderless resistance theory illustrated that there is a lack of cohesiveness movement within and relies on the unilateral approach. This made it easier to differentiate between individuals and organizations, which assisted in identifying characteristics of lone wolf terrorists. Atran (2006) stated unity is not always promising, especially after seeing the leaderless resistance transformation of Jihadist networks in the wake of diminishing group networks.

Although it is not in the best interest to overstate the engagements of leaderless resistance, leaderless resistance as a concept is broadly talked about. The fact that the attacks are so far and few in between makes it a complex task to understand the "how" of lone wolf terrorism. Seeking information that pertains to this terrorist threat is important to finding few answers to the many questions that go unanswered (Bakker \& de Graff, 2010). 
According to Steward (2011), for all who have been paying attention to the news as of late, the media has been overwhelmed with a steady stream of statements regarding lone wolf terrorists:

While many of these statements, such as those from President Barack Obama, Vice President Joseph Biden and Department of Homeland Security Director Janet Napolitano, were made in the days leading up to the $10^{\text {th }}$ anniversary of the 9/11 attacks, they did not stop when the threats surrounding the anniversary proved to be unfounded and the date passed without incident. Indeed on Sept. 14, the Director of the National Counterterrorism Center, Matthew Olsen, told CNN that one of the things that concerned him most was finding that next lone-wolf terrorist before he strikes. (p.1)

One reason the leaderless resistance model is advocated is because it creates fear and uncertainty. There is a belief that at some point, lone wolf terrorists will not have the choice of network affiliation.

Leaderless resistance theory is useful and relevant to explore the factors that influence, contribute, and justify an individual pathway to terrorism. This model further examined the advantages and disadvantages. An advantage of using the leaderless resistance model is that it makes lawsuits and prosecutions (Civil and RICO) more complex. However, by using this model, the lone wolf is not able to sustain key methodological objectives because of a lack of coordination. Leaderless resistance theory demonstrates how the following has become dysfunctional and unorganized. It also 
demonstrates that there are few established leadership hierarchies that would be recognized within the general population.

The leaderless resistance theory has evolved from Islamist threat. The value of using the leaderless model is that it puts the threat into context. The leaderless resistance theory presented ways to address how lone wolf terrorism came about, thus offering a unique opportunity to understand the issues that impose a great deal of pain among the masses. This study addressed the insufficient examination of this phenomenon formulated by the theory versus its practice. The decision to study lone wolf terrorism was compelled by less attacks at home being grouped (organizations), making it difficult for national security to stop the violence and mayhem from increasing domestically. Conveying the correct information is a critical step in dismissing the mystique and addressing the problems posed by such individuals in a realistic and rational way. The examination of literature to understand how the leaderless resistance theory relates to lone wolf terrorist in the U.S. was considered by their very own nature. Other theoretical models considered included the Van Gelder (2013) rational choice model, which considers the cost versus benefits of crime focusing on the individual's decision making. Mose's (2010) model reviewed the role of attitudes in bad behavior for participants with multiple problems, such as anger and psychological impairment. They both identified potential reasons of why, but neither accentuated the attacks are less vulnerable to the traditional methods of national security. 


\section{Leaderless Jihad: The Modern Face of Terror}

Muslim extremists account for a small number within the population. If a small number of Muslims account for a small percentage, then why are many juvenile Muslims led to extremist versions of Islam through grassroots radical establishments within their social community? What makes them become extremists? How can violent extremism be fought and routed? In Marc Sageman's book, Leaderless Jihad: Terror Networks in the Twenty First Century, he discussed all the above questions. Marc Sageman, who is a counterterrorism consultant and forensic psychiatrist, provided a thorough consider the current global Islamist terrorist threat, exploring its progression from the 1980s through the latest wave of terrorism (Arndt, 2011).

Waugh (2006) noted how, in the book Leaderless Jihad, Sageman continuously fills in and adds to his prior work on what causes extremist elements of terrorism within their social community. He also noted that Sageman's work is unique, because of his “data-based" approach to al-Qaeda's study. Throughout the book, he organized individual terrorist profiles to garner data in relation to their characteristics, psychological factors, risk factors, and mindsets. The al-Qaeda-led Islamist terrorist following contained thousands of individuals. It is comprised of terrorist networks that got together in route to terrorism. The networks may perhaps develop into official organizations like al-Qaeda due to shifting circumstances (Alexander, 2009).

Even though al-Qaeda's core is centered alongside the Afghanistan-Pakistan border, the radicalized terror following has evolved and grown beyond its grassroots origination (Gartenstein-Ross, 2009). Today's al-Qaeda and terrorist networks have an 
offspring as the result of several chronological terrorism cycles. The veterans of antiSoviet following in Afghanistan, who collaborated with Osama bin Laden, were the first cycle of al-Qaeda's following in the 1980s. Individuals who went and trained through alQaeda's training camps comprised the second wave of followers. Al-Qaeda's core was major during this cycle, personally sending their terrorists all over the world (Said, 2012). Cox (2009) said nonetheless, the third wave, are the individuals who emerged in the post 9/11 era, those who connected to the al-Qaeda following during the outing of the Taliban when U.S. led invasions into Iraq and Afghanistan. Al-Qaeda has lost many of its training camp facilities and the locations where they were once deemed safe. But their social following is more encompassing than before due to the global use of the Internet, where the organization has had success in radicalizing a new breed of individuals, including many who are among the second-following of Muslim individuals in North America and Europe. These were the followers, for example, that went and carried out terrorist acts on the London's transportation system in July 2005.

Sageman wrote that the third wave of individual followers feel that they are heroes, regardless of right or wrong, and therefore they transitioned during this cycle:

Sageman asserted, the course of their radicalization is a result of an individual's logic to what he perceives his affliction to be of what his fellow Muslim followers are going through around the world; no matter if his affliction is in grievance with his own experience, for instance, obscurity in making the West and, at last, organized networks that lead individuals sequentially to violent radicalization by using terrorist cells (Tucker, 2010, p.1). 
Sageman suggested making terrorism less eventful as an alternative method to the social following movement encouraged by al-Qaeda (Sustein, 2008). Juvenile Muslims can be better suited if they are a part of the solution to resolve the local clashes that are intensified by al-Qaeda's propaganda in the Muslim community. Juvenile Muslims are deemed heroes if they join the movements, so they should have alternative choices and individual freedom without being force or manipulated in joining al-Qaeda's movement.

\section{Shift Toward Leaderless Resistance}

There is no doubt that the threat of lone wolf terrorism is serious, but one must first recognize its history. To say lone wolf terrorism has been in existence forever is like saying it is a natural part of society. History has shown that lone wolf terrorism today is very similar to past terrorism that emerged in the 1800 s, when fixated individuals like Leon Czolgosz were so adamant on changing the political situation. Leon Czolgosz, the anarchist who assassinated U.S. President William McKinley in 1901, was a lone wolf, according to the University of Buffalo (2013).

In 1971, The National Alliance was created by a White supremacist who called for the segregation of whites from others, specifically Jews (National Alliance, 2011). The National Alliance is a network dedicated to advancing the ideas of the deceased founder William Pierce, whose core beliefs are strictly in the realm of white supremacy. William Pierce was one of the defendants of Fort Smith in 1989 that wrote a novel titled Hunter, in tribute to a fictitious lone wolf. The book was intended to be a guiding treatise for lone wolves like Joseph Paul Franklin, to whom the book was, dedicated (National Alliance, 2011). 
According to the Anti-Defamation League (ADL) (2013), Richard Kelly Hoskins was another white supremacist, but he was not as well-known as William Pierce. Hoskins was a financial advisor in Virginia, and he advocated for racism for nearly five decades, reasoning for the far right during the last two decades. He wrote many Christian-based commentaries that were popular at supremacist symposiums and sanctuaries. He was well-known for the concept of "Phineas Priesthood." Those were white supremacists that used violence to retaliate crime against the white race.

Louis Beam, a Fort Smith defendant that hated the government, developed concepts in an essay entitled "Leaderless Resistance" in 1992. The essay contained an orthodox pyramid scheme of an organization and he thought it was not only useless but also very dangerous. He supported and argued that it was best to continue the military and ideological fight through independent cells (Beutel, 2007). The movement or following has not flourished the way white supremacists like Pierce, Hoskins, and Beam envisioned it. Even before the 9/11 attacks, several decades had gone by since the rise of leaderless resistance. The success of lone wolf attacks has faltered due to the penetration of the government; this is exactly why those leaders shifted to the leaderless resistance to further the White supremacy agenda.

To date, the leaderless resistance model is not only used by the far-right wing, but the left wing adopted a similar model as well. They specifically supported the Earth Liberation Front (ELF) and the Animal Liberation Front (ALF). The ELF and its partnering network, the ALF, is environment friendly and against the progression of manufacturing if it is not for the bettering of the environment and animals (Anti- 
Defamation League, 2013). ELF and ALF are very smart and dissimilar to Islamic terrorists. They want people to see what they are doing, unlike others, and they would rather attack property than people. The crimes are usually associated with burnings and property damage.

Bjelopera (2011) stated, over the last decade, jihadists for some of the same reasons have taken a leaderless resistance approach. The group approach from al-Qaeda has transformed into a leaderless approach. The twenty-first century of Islamic terror networks seems to be more loose, self-regulating, and have more random entities than their prior groups, who were a part of the September 11 atrocities. The concept has gone from the network of top al Qaida officials, scheming enormous resources and giving orders, to a huge number of low network members that are trying to execute leaderless jihad from the bottom up.

Lone wolf terrorists may not be physically supported or have the guidance of figureheads from a network, but they form a very violent social following using the Internet. Terrorism has always been associated with the Middle East and other countries across seas; yet, it has migrated to Western countries. The challenge in the twenty-first century for governments is trying to stay one step ahead to detect and neutralize these individuals before they become violent. To have any type of success against the threat that is very much real and dangerous, the process must first be understood, which has consequences for Western governments if they cannot detect the threat during the process (Sedgwick, 2012). 


\section{Lone Wolf: Characteristics, Psychological Factors, Risk Factors, and Mindset}

Finalized reports from research summaries have shown that lone wolf terrorists who individually commit solo acts of terror on their own behalf, away from established terrorist organizations, constitute a growing threat toward U.S. national security. The characteristics of lone wolf attacks have prompted differing assessments upon commutative reports. Gruenewald, Chermak, and Freilich (2013) stated that far-right extremist usually consist of the military, the least to marry, those who envision dying at the scene of the crime, hanging out alone, firing weapons, shooting multiple victims, and choosing government targets. These same characteristics are also the distinguishing factors from each other.

Lone wolf acts, in comparison, are more significant and have brought a new sense of a new awareness from national security. The U.S. government examined the characteristics regarding lone wolves in two forms: school attackers and assassins (McCauley, Moskalenko, \& Van Son, 2013). The results revealed that lone wolves were mainly white males, and both groups of individuals were dominant lone perpetrators. Conversely, military service, marriage, and education varied in relation to assassins than school attackers. They seemed to be older, or adults that had more years of opportunity to achieve entering the military, getting married, or getting a degree versus the school attackers (McCauley et al (2013). The other demographic characteristics, as documented by McCauley et al (2013), are also displayed in Table 1. 
Table 1

Themes Derived from the Data Analysis of Lone Wolf Characteristics

\begin{tabular}{lcl}
\hline & $\frac{\text { School }}{\text { attackers }}$ & Assassins \\
& N=41 & 7083 \\
Lone Actor & 100 & 86 \\
Male & 76 & 77 \\
Caucasian & $11-21$ & $16-73(\mathrm{M}=35)$ \\
Age range & $0^{1}$ & 55 \\
Served in military & $100^{1}$ & $49^{2}$ \\
Never married & $100^{1}$ & 54 \\
High school education or less & 27 & 66 \\
Ever arrested & 24 & 39 \\
History of substance abuse & $78^{3}$ & 44 \\
History of depression or despair &
\end{tabular}

${ }^{1}$ Percentage assumed, not explicit in School Report

${ }^{2}$ Corrected percentage, $41 / 83=49 \%$, where Assassins Report gives $51 \%$

${ }^{3}$ Percentage reported having suicidal thoughts or suicidal attempts 
As reported above, school attackers are much younger than assassins. The U.S. government report shows no military entry for school attackers compared to about $50 \%$ of assassins. Forty-nine percent of assassins had never married in comparison to school attackers who never married. Both groups' criminal records differ greatly. Not knowing assassins' arrest records as teenagers makes it difficult to interpret. Depression, despair, and a history of suicidal thoughts vary tremendously with school attackers (78\%) and assassins. Surprisingly, school attackers had a higher percentage, although assassins were much older and had more of an opportunity to achieve such things (McCauley et al., 2013).

\section{Psychological Factors}

Three psychological factors emerged as contributors to the radicalization of lone wolves: group relative deprivation, identity conflicts, and personality characteristics (King \& Taylor, 2011). The lone wolf terrorist seems to feel some sort of deprivation, which is essentially the mind-set that occurs because of feeling not equal, in a sense, and unspoken within a group of individuals. This concept was first seen in Stoufer et al.'s (2005) work about no formal explanation of the concept or course of action regarding its examination. Crosby (2006) had a different explanation and his reviews emphasized the concept of relativeness: deprivation is felt in relation to others with the aim of comprising a reference group (Barcena-Martin, Imedio-Olmedo, and Martin-Reyes, 2007).

Identity conflicts can be inspired by many things, but identity regarding a religious following is known to be amongst the most intriguing, due to the holy views they are associated with. Religion is associated with the spiritual uplifting of an 
individual, bringing out a person's sense of belonging and conviction; it also leads to small-mindedness, prejudices, and radical aggressiveness (Agbiboa, 2013). Each of us sees the world from a different perspective and this can cause conflicts, especially when individual can only view the world from his or her perspective.

Merari, Diamant, Bibi, Broshi, and Zakin (2010) had shown major differences between personality characteristics that were found between lone wolves that were and were not suicidal terrorists. There were two central personality characteristics found among the would-be suicides. One group of lone wolves were found to have low levels of strength and were independent and had an anti-social personality, a characteristic that made them less likely to be in a group and least likely to have social influence. Others were examined as being emotional and/or having a deranged life style.

\section{Risk Factors}

Because of the perceived threats of lone wolf's post 9/11, The U.S. Department of Homeland Security (DHS) has nullified counter-terror measures, and work is ongoing to expand others. Lone wolf terrorists are flexible and tend to shift their strategies, methods, and events when countermeasures are put into place, different from normal or unplanned man-made disasters. When trying to gage the lone wolf, it is difficult due to the limited data which makes it hard to confront the threat. Examining the lone wolf terrorist groups operating outside of the established leadership hierarchy is a challenge for all securing officials (Lemieux \& Regens, 2012).

DiRenzo and Das (2012) used the Global Terrorism Index (GTI) and found that state revenue has a major relationship connection when evaluating the terrorist risk, after 
considering all other implications that were associated with terrorism. The findings urged them to look at the GTI data variables to further examine the relationship between revenue and income. Particularly, state revenue was found to be a major correlation with other states' counter-terrorism measures or the deterrence risk factors. The debate is that states with more money have larger capabilities to employ counter-terrorism and security measures than states with less money.

According to Schmid and Jongman's classic book, Political Terrorism, the grassroots origin of terrorism lays in oppression. Many scholars have given different advice in relation to risk factors for lone wolf terrorism. Many focused-on group followings, the individual's state of mind, their environment, or economic conditions. However, many talk about the oppression as an annoyance. Walter Laqueur distinctively said that oppression and terrorism are conversely linked (Victoroff, Adelamn, \& Stern, 2006).

\section{Mindset}

White (2010) said that the mindset of lone wolf terrorist involves his or her logical and responsive nature on the topic of a given situation or threat. This element is the first phase of decision making and included the terrorist who may be at the forefront and center of the situation and must decide to either participate, or not get involved with the situation at hand (perceived threat). If he or she chooses to not get involved, then he or she will bypass the following issue. However, if they choose to participate in the situation at hand, they must follow through and evaluate how they are going to attack this threat. When they feel comfortable and ready to take on with what they perceive to be a threat, this is when their confidence will rise and allow them to begin the next phase. 
Lone wolf terrorists are believed to commit terrorist acts because of various motivational factors. It is well-known that established terrorist organizations employ social and psychological strategies to brainwash individuals into their ideological mindset. They use strategies to convince and simplify the phenomenon around the individual. Because of the individuals' likely economic and social conditions, it is only a matter of time before these strategies begin to work and these individuals become terrorists. Nonetheless, it mirrors the effects of motivational factors in becoming a lone wolf terrorist (Eren, 2007).

Basibuyuk, Karakus, and Akdogan (2007) noted fundamentalism is associated with the mindset or base, especially when it comes to religion:

It is referred to as the core template. This is one of the most debated concepts among scholars and theologians. When a person is looking from the outside in, fundamentalism is usually associated with being stigmatized, a scornful title "associated with private, coldblooded, and strict behavior." Equally, carrying the title of a fundamentalist can also be a foundation of morality and superiority for exclusives who like to see themselves as showing pure faith in obeying religious commands.

Even though fundamentalism can be related to concepts or a set of identities or be viewed as a collective phenomenon, it also has an individual element and perception.

\section{Lone Wolf: The Most Significant Threat to U.S. National Security}

Over the next several years, the most significant homeland terrorism threat will come from the lone wolf terrorist. They are inspired by established terrorist organizations 
but act on the peripheries of those movements (Kouri, 2011). With all the mayhem subsiding in the Muslim communities, established terrorist organizations will attempt to recruit more individuals on behalf of their organization. These unknown and unidentified individuals are mysterious to leadership within terrorist organizations, but these individuals present the most significant threat to the U.S. It is assumed, because of international cooperation and collaboration in the realm of international terrorism, there will be a further decline in group terrorism. Sagers Herzog (2013) said to make no mistake, lone terrorist threats are and will continue to be the most significant threat to national security.

One thing terrorist organizations have done was collaborate with each other and will continue to do so to accomplish their desired end goal against the U.S. These organizations might be bound by range, but their free lancing will challenge the U.S. government to counter the threats and/or attacks. Al-Qaeda and their loose associations will continue to be the most significant threat over the next several years, according to Mike Snopes, who is head of a security firm and a former police commander in New York (Lasky, 2012). The FBI (2013) predicts that administrative districts and agencies outside of the government will have a growing role in world events for future years to come, showing new disproportional threats to the U.S.

The U.S. may take the lead in trying to thwart the lone wolf threat and/or attacks, but other nations will likely play a critical role. Governments are going to have to extend some control through capital resources, services, and employees (Preble, 2011). The administrative districts and agencies outside of government will likely be first responders. 
Despite the limited resources, it does not cost much for lone wolves carry out attacks. For example, James Holmes, who is an American, entered a movie theatre in Colorado and killed at least 12 people and wounded more than 50 in his lone melee. When the attacks are successful, they usually are high-profile, very dangerous attacks, and their plan is extremely challenging to detect. With the globalization of technology that continues to network world economies, the economies will become more reliant on each other in years to come. Some parts of the country will stabilize, but the income gap between nations and cities are likely to make some countries and individuals a hotbed for terrorism.

As national concepts and boundaries become more complex and global, the distinction between national and international themes will blur. This will threaten national security by creating and linking national and international terrorist prospects or criminal organizations. Most scholars say the more technology is developed, the more it will have a profound effect on the collective ability of governments to protect this nation. With current technology advances, the process is transforming and will continue to transform. The U.S. and other countries are going through the most significant global transformation. The U.S. has seen no other like it since it went from an agriculture nation to an industrial nation. The transformation and technological advances allow lone wolf terrorists to access many things like weapons technology unlike the pre-Internet era (McComb, 2013).

Shea (2013) stated that technological advances have allowed lone wolves to stay one step ahead of national security. For example, stories have been on the news in relation to individuals purchasing poisonous gases or biological warfare agents, and how 
challenging it was for national security officials to trace where the specific agent was bought. In the 21 st Century, terrorism is no longer associated with the Middle East; it has no confinement to any territory and neither do the criminals. Instead, they see this as a major opportunity (Asal, Ackerman, \& Rethemeyer, 2012).

Lieber and Press (2013) talked about how nuclear weapons and terrorist acts have already been a topic of discussion, but this discussion is expected to increase considerably. With what we already know about terrorist tactics, the expectation for them to try to secure nuclear weapons is something that is feared and dreaded. Technological advances made it simpler to move nuclear material around the world. As with the iPhone, the basics of nuclear science and technologies are more easily understood, enabling terrorists to produce nuclear weapons. Similarly, basic materials are readily assessable to obtain (Mauroni, 2013). Terrorist threats in the homeland have only scratched the surface and will continue in the U.S. for the next several years. The once-proud tradition of farleft groups who tried to overthrow the U.S. government because of the manufacturing advances seems to have gone away in recent years. However, new individuals or groups have emerged that can amass new threats.

The states that perceive the U.S. to be their biggest threat or rival will likely remain that way or increase that perception. The most looked-for U.S. targets will be governmental and armed forces' strategies and objectives, expertise, and capital establishments; individually, governmental and non-governmental. Intelligence officials from other nations will increase their targeting scheme to recruit U.S. personnel overseas by using informal techniques and collections methods to further their agenda (Klein, 
2012). With the advancement and secure methods of technology, intelligence officials from other nations will use this method to draw upon individuals and to characterize the procurement of secure technology methods to discreetly post all over the United States.

\section{How the Theory Translates into Practice}

Emerging lone wolves will be able to be more discreet, making it more complex for national security officials and intelligence agencies to apprehend them. More recently, this can be illustrated by examples such as the Washington Navy Yard shooter Aaron Alexis, and Umar Abdulmutallab, the Christmas day bomber who had hidden explosives taped into his underwear in 2009. These attacks are less costly, but they are very violent and dangerous. Lone wolves and micro-cells do present sole challenges, but transforming beliefs into actions has proven to be difficult. For every Timothy McVeigh and Nidal Hasan, there is an Umar Abdulmutallab, the lone wolf that fails often due to a lack of resources, faulty structure, or the fact that they are apprehended before the attack can occur.

Very seldom are there lone wolves who have the skills, will, and the combination of resources to carry out a successful lone wolf attack. When they can translate theory into practice, the result is success. Failed attacks are associated with irresponsibility and a lack of patience and skill. The lone wolf frequently miscalculates the attack and does not have a good assessment of the target, which is often far beyond their capabilities. When they attempt something that is beyond their measures, it often results in a complete botched attempt (Pantucci, 2011). 
Teich (2013) mentioned that the ability to become a lone wolf does not require any skill or experience. All that is required is simply a resistance to a lifestyle and the ability to carry out attacks. Those skills and experience can only come with time, and the best chance for success lies in small victories. Small victories fare better than one giant blotched attempt, which may likely be his or her last attempt as a lone wolf. Every second and every level of resistance counts. Information is the key and successful attacks align with planning accordingly and avoiding prior mistakes by their predecessors.

Since the attacks are individually manned respectively, he or she is exposed to detection at some point in the process and therefore must avoid riskier situations, like being detected by cameras, to reduce the risk of detection (Stratford Analysis, 2011). It takes more effort in to bomb a large building than using a meek box cutter knife. Although the latter does not require much effort, the lone wolf still must plan the steps. The advantage of using the leaderless resistance is that there is little to no communication, which complicates the process.

Acting alone simply requires a lot of time, self-training, and for him or her to collect all the required resources prior to an attack. Considering what it takes and requires for an individual to transform a belief into action (lone wolf theory to practice), there are not many individuals who possess these skills to carry out attacks. It can be concluded, in part, why this theory has been around so long and why there have not been more attacks, despite the fact of the media polarization (Andrews, 2009).

Undoubtedly, lone wolves do present a threat, but that threat should not be exaggerated or ignored. Lone attackers are not mythological individuals that impose 
harm. Lone wolves follow a process and are vulnerable to detection. Examining the phenomenon is a critical step in dismissing the mystique and addressing the problems posed by lone wolves in a rational and practical way.

\section{Preventing Lone Wolf Terrorism}

In the realm of homeland security, there has always been the following question: do we sacrifice individual freedom to prevent the next terrorist attack? Most Americans do not want to sacrifice individual freedom. Individual freedom is one of America's greatest assets and liabilities. Preventing the next terrorist attack require a compromise of what we have treasured for over two centuries: individual liberty. Downing and Mayer (2013) said that national security must take what it has learned from the Boston marathon attacks and answer a vital question: how can the U.S. create an operative security net involving state-run and local law enforcement organizations?

The U.S. would benefit more if organizations were developed to the extent of how the FBI was introduced in1908: to create an additional level of expertise and specialization toward lone wolves and to share critical information beyond certain jurisdictions. Intelligence agencies lack information sharing because of federal and state policies. This culture can no longer be tolerated and must quickly change to prevent the next lone wolf attack.

Lone wolf attacks are often difficult to carry out, but that does not stop the state of the threat (Coffey, 2011). Reports surfaced that the FBI had information on the Boston suspects, but because of the advice on behalf of the United States Attorney's Office, they could not share it. If this was the case, a few things should happen: Congress should 
rewrite legislation allowing information to be either passed or shared, or reevaluate the organization that is holding such information (FBI, 2013).

Ritchey (2013) talked about the power of partnerships, particularly, the FBI's lead role in the Boston bombing case. The lone wolf committed a crime before it became an act or terror. If the FBI would have shared the intelligence with the local police department the attack could have been prevented. The lack of information sharing between federal and state law enforcement organizations hinder investigations and create gaps within the intelligence. This is where such policy and legislation would benefit national security and potentially save lives. Best practices should be revisited in terms of the legal structure and formality.

Governmental entities are less likely to distribute any information that may prove harmful when a series of practices arise in a case like the Boston bombing attacks. Investigators are subject to restriction with information sharing and this policy has allowed attacks to be underwritten at home. In contrast to the federal government, lone wolf acts confront minor challenges since the cost of terrorist attacks are minimal. Individual acts require less resources given that they do not operate under an established terrorist hierarchy, field commanders, engage with others or propaganda dissemination, operate openly or deliver goods (Perlmutter, 2013). Criminal cases shall be handled locally rather than by the federal government.

It is a challenge, and it is intensely difficult in identifying the next lone wolf terrorist. Sacrificing individual freedom will never totally eradicate the threat of terrorism; this would only hamper individuals' freedom, which makes this nation the 
best. The U.S. can, however, make changes constitutionally that would enhance the chances of detecting lone wolves and averting future lone wolf terrorist attacks.

\section{Social Change Mechanism}

Assessing the change process regarding the greater security concern requires an understanding of the phenomenon. Moreover, an assessment is needed to look at the underlying mechanisms and processes that lead individuals to be drawn to or away from existing radical movements (TTRSL, 2008). This study addressed the gap by studying the individual phenomenon as oppose to the group phenomenon.

As stated by Mendelson (2008), terrorism is an inter-reliant structure of elements and individuals, and a more comprehensive understanding of the lone wolf terrorist phenomenon can be assessed by viewing it in a multifaceted scheme. Scholars normally view lone wolf terrorism as a group phenomenon to get general understanding; a single examination starts with the identification of an individual (lone wolf); examining the elements of that greater society, and then viewing the problem or phenomenon within that greater society. The view from many scholars and securing officials is that a major challenge and/or limitation of the leaderless lone wolf are that they are hard to detect.

As Stewart (2011) said, it is very challenging to separate between those radicals who have every intention to commit terror acts from those who just voice their opinion. To distinguish the probable lone wolf before they act, national security officials must use unlimited resources and time searching for these individuals. This is a frightening assignment, considering the vast number of potential suspects that are out there. A consortium approach between all levels of government will help take on these challenges. 
Another change that can help effectively achieve this goal is that they require consistent engagement from all businesses and communities.

\section{Summary}

Identifying the lone wolf terrorist, whose attacks are high profile, very dangerous, and extremely challenging to detect, before they act poses a significant threat to national security, and is the essential reason national security officials are concerned. Lone wolf terrorists act alone from established hierarchies, forcing national security officials to try to comprehend the "how and why" he or she transform to a terrorist. National security officials must identify individual terrorist activities carried out by those individuals from those carried out as a part of terrorist networks. In concern of the potential impact of lone wolf terrorism on national security, characteristics regarding the lone wolf terrorist formulate a knowledge base to identify potential suspects.

As indicated by FBI Director Robert Mueller (2003), lone wolf terrorists, those who individually and independently commit solo acts of terror on their own behalf away from established terrorist organizations, are the most difficult to seek out before they act and hence pose a huge security concern. No statement was more significant than Hoffman's forewarning in 2013. Homeland terrorism in the United States today may be more of a threat than global terrorism. The homeland terrorist threat in our country constitutes the framework to explain the phenomenon as a new strategy to show the diminishment of terrorist and insurgent movements internationally.

The leaderless resistance model forms the theoretical basis for setting aside the mystique of the lone wolf and examining the reality of the phenomenon. Leaderless 
resistance theory introduced by Ulius Amoss in 1962 personifies concerns related to lone wolves. As stated by Michael (2012), what caused individuals to unilaterally take violent actions in the name of a political or social cause remains an area of concern. Lacking a known, identified, or established leadership hierarchy, these troublesome individuals challenge the imbalance of power that manifests itself as a lone wolf, surfacing as terrorists or radical extremists, thereby creating difficulties to be stamped out. The implication of leaderless resistance theory to lone wolf terrorism is that the problem focuses on the phenomena aspects of the leaderless lone wolf terrorist and the underlying mechanisms and processes that lead individuals to be drawn to or away from an existing radical movement, to act unilaterally and without direction toward violent ends.

For the lone wolf, building upon previous research for establishing a qualitative phenomenological approach was appropriate to address the threat of lone wolves. Lone attackers have demonstrated the threat they pose. They follow a pattern and are susceptible to exposure at some point in the process. Identifying this process is essential to addressing the problem posed by these individuals in a rational and practical way (Bjelopera, 2012). The leaderless resistance strategy was used to help identify intangible factors such as social norms, socioeconomic status, gender roles, ethnicity, and religion, whose role in the research may not be clear (Creswell, 2009).

Similarly, Phillips (2011) discussed how the individualistic nature of lone wolf terrorism might, however, command more subtleness from several economic, theoretical models that may lend themselves to its analysis. The reviewing of literature provided insight into lone wolf terrorism and the changes that need to be made to address the 
greater security concern. Lieberman and Collins (2011) pointed out that the role of national security is to involve others, such as the Attorney General, the Director of National Intelligence, the Secretary of Homeland Security, and direct coordination from the federal government to local levels of government. It is very important that the agencies be on the same page and have the proper training during the investigative process. Legal ethics training must be given to elude any violations of human rights and decisions that otherwise may violate civil freedoms (Bryneilson et al., 2013). While Lieberman and Collins's plans suggested that role of national security should involve others and additional training, Stewart (2011) stated it is very challenging to separate between those radicals who have every intention to commit terrorist acts from those who just voice their opinion of hate and/or radical beliefs. To distinguish the probable lone wolf before they act, national security officials must use unlimited resources and time searching for individuals who may be transitioning their extreme beliefs into actions. Chapter 3 presents a qualitative research design as a method of study, consisting of secondary data analysis from the RAND and GTD databases. 
Chapter 3: Research Method

Lone wolf terrorism has been described as a convenient method for individuals to plan and conduct terrorist attacks by way of avoidance and a lack of detection. This study addressed factors beyond the general qualities of lone wolf terrorists. I examined whether factors such as social norms, socioeconomic status, gender, ethnicity, and religion affect the lone wolf phenomenon. This chapter includes the study design and how the data were collected and analyzed.

When I conducted the study, I realized many advantages of qualitative research and a phenomenological design. I could understand the phenomenon by exploring the totality of data. In addition, qualitative research helped me uncover trends in the thought process of lone wolves and immerse further into the problem. Notably, I was in control of the study and it allowed me to explore the phenomenon in its natural setting. The qualitative researcher does not need to control the environment as in quantitative studies, which rely on numerical data (Qualitative Approaches, 2013). I sought answers to questions that underline how the phenomenon was formed and given significance.

\section{Research Question}

The following research question was used to guide the study: What are the underlying mechanisms and processes that lead individuals to be drawn to or away from an existing radical movement and to act unilaterally and without direction toward violent ends? The sub questions were as follows: What causes an individual to participate in lone wolf terrorism? Are there consistent and significant indicators that can characterize a potential lone wolf actor? 


\section{Research Design and Rationale}

To answer the central research question, I explored aspects of the leaderless lone wolf terrorist and its mechanisms and processes. An inclusive study of lone wolf terrorism was needed to promote U.S. national security. To identify the factors related to the phenomenon, I chose a phenomenological design.

The rationale for using a phenomenological design is that it allowed me to focus on the experience of the individual regarding the phenomenon (see McNabb, 2010). The phenomenological design is ideal when the researcher seeks to gain a comprehensive understanding of a difficult problem and to broaden the practices of prior research (McNabb, 2010). The central question influenced selection of the research design. According to Creswell (2009), phenomenological inquiries are conducted to explain the phenomena according to the lived experiences of individuals. Qualitative research focuses on achieving a thorough understanding of a phenomenon or a type of experience (Creswell, 2009). Because there were limited studies involving lone wolf terrorism, it was challenging to find data. Most studies conducted on terrorism involved a group perspective, which limited the understanding of lone wolf terrorism. (Horne, 2012).

\section{Qualitative Approaches}

When deciding on a qualitative phenomenological approach, I considered four other approaches: narrative, grounded theory, ethnographic, and case study. The narrative approach focuses on the hierarchy of social data. Furthermore, the narrative approach assumes that information is valuable and noteworthy even if it is known by only one 
individual (Creswell, 2007). However, 177 individuals and incidents were included in this study.

Grounded theory involves a bottom-up approach. A theory is developed from the process of collecting data and systemically coding it (Small, 2009). The intent of the current study was not to develop a theory for leaderless lone wolf terrorism. According to small (2009), ethnographic studies include trends and actions to get a better idea of the relations involving social clusters. This approach was not appropriate in exploring lone wolf terrorism because lone wolves might share common characteristics as a group, but lone wolves are not a group phenomenon. Case studies are limited by intervals and activities, which were not relevant to the current study (see University of South Alabama, 2013). This study was conducted to understand the challenges and threats lone wolves pose to national security, and to explore individuals who share common characteristics and goals. The University of South Alabama (2013) stated that the examiner's intent is to gain a pathway into the participant's life experiences and the way the individual sees the world. The phenomenological design was best for this study.

\section{Phenomenological Design}

A phenomenological design is an effective way for the researcher to translate the personal experience of individuals into their personal perspective (Creswell, 2009). The design enables the researcher to develop a real-world theory to advise, assist, or contest a course of action (McNabb, 2010). Data on lone wolf terrorists were limited, and only studies that dissociated the lone wolf from the group phenomenon could address their 
unique experiences. According to Creswell (2009), to gain a better understanding of the phenomenon, the researcher must analyze the role played by the phenomenon.

Phenomenological research has developed into several methods and approaches to studying the lived experience of others. Phenomenology is used to investigate the origin and practice of something or someone (Sonoma University, 2013). Researchers often use the term when describing an approach to qualitative inquiry. Merely, phenomenology is a way of thinking that underlines a focus on individual experiences and how individuals see the world (Qualitative Approaches, 2013).

\section{Secondary Data Selection Process}

Secondary data selection is defined as the process of determining the suitable data, source, and the appropriate tools to collect data (Silverman, 2016). Prior to importing documents into NVivo (software), I selected data that were only relevant to lone wolf terrorism in the United States. The term differentiates data choice from data reporting (not using data that has no relevance to your study) and collection (secondary data analysis). The process allows researcher to choose the data that is the most viable to the study (Silverman, 2016).

I selected the data documents and tools to sufficiently address questions. This selection is specific and is driven by the nature of the research project, current data, and the availability of data sources (see Marshall and Rossman, 2014). Ethical problems arise when data is based upon convenience and cost rather than proficiency to address the questions (Marshall and Rossman, 2014). Convenience and cost is important when and 
data selection precedes data collection. The process of selecting suitable data for the study can comprise the data integrity of this study (Glaser \& Laudel, 2013).

Secondary data collection was driven by the nature of the study, current literature, and accessibility to essential data sources. The appropriate data came from many sources and was lone wolf specific. Secondary data analysis was convenient and less costly because the information had been researched during the qualitative research process. The accumulation or pre-establishment of data helped because I would not have been able to collect a rich amount of data.

In addition, I use secondary data create a suitable phenomenological design to compare data analysis. Before I conducted the study, I made sure the data was aligned with the research questions. This allowed me to review similar sources of data and the data collection method. Secondary data was excellent to use not so much for the analysis of the pre-established information, but as a pre-designed study. The substantial amount of information available displayed pre-established levels of validity and reliability.

\section{Data Collection}

Current literature on lone wolf terrorism is sparse, but can be presented in numerous of ways. Few studies that have been conducted on lone wolf terrorism and it is difficult to extricate the data type and source that is few and far between. The goal of data collection was to select data that was representative of lone wolves domestically. National security officials can devise a plan and or form solutions from the suitable data. Failure to share information may underwrite further lone wolf attacks. 
Secondary data collection in this study was retrieved from the RAND and GTD databases to research lone wolf terrorism. Both are electronic filed databases and compose of inclusive files regarding terrorist acts or efforts. Secondary data such as interviews, field notes, surveys, and other sourced material regarding lone wolf terrorism was examined. Data was assembled and filed from acts and efforts that had previously occurred. The databases were organized accordingly by date (after 9/11/01) and location (U.S.) and by the characterization of lone wolf terrorism outlined for the reasons of this study.

When I carried out secondary data analysis, I examined the relationship between primary data and secondary data. I wanted to make sure the study questions from the analysis were identical to those of the previous study, and the primary data collection analytic techniques was applied to the secondary analysis (Northern Arizona University, 2013).

\section{Data Analysis Methods}

Once all the suitable data was gathered, individual source data (audio files, transcripts, etc.) were produced for each of the individuals. I coded and divided the data into themes and it allowed me to categorize qualitative data and explore the scheme and specifics of the categories. The process begins with open coding, allowing for small amounts of data to be entered while developing other preliminary categories. The coding became more selective in terms of concepts and codes that were entered (Qualitative Approaches, 2013). NVivo qualitative analysis software was used to analyze source documents, whereas the analysis was more profound. Instead of manually analyzing the 
data, NVivo analyze the source documents, which allows the researcher to build theories to answer and support the research questions (UCONN, 2013). Although, programs like NVivo are used to analyze source data, the data was also manually coded and recorded in the study for comfortability.

When analyzing the source data, there were several steps. First, I was able to analyze and make sense of the data type and source. Second, I analyzed the data by going over it repeatedly (most of the qualitative researchers call this process "peeling the skin off the potatoes" in lieu of the data, and making an analysis (Creswell, 2009). Any cues from transcripts and/or interviews were used to verify and validate source data. The process was a guide and it limited potential biases to draw conclusions from the vast amount of data in the electronic databases.

Qualitative research studies should be judged on the qualitative paradigm. Qualitative research is recognized and respected in its unique approach to terrorism (Qualitative Approaches, 2013). However, many critics believe that findings are often biases, which threatens the credibility of qualitative research. Also, critics believe this could be minimized if the researcher excludes personal opinions and beliefs. When analyzing the data, I compared NVivo and Microsoft workbook.

\section{Ethical Issues in the Use of Secondary Data Analysis Research}

Secondary data has disadvantages. When conducting secondary data analysis, consent from individuals should be obtained (Sringernyuang, n.d., p.1). Walden's University approval and consent was required before I went forward with the data collection. Many times, the data originally collected for the study, may not be in the 
original format and/or may be difficult to obtain the right of entry in a public domain database. Sringernyuang (n.d.) stated that, when gathering information from a public domain like RAND's database, anyone could partake in secondary data analysis. There is a lack of guiding principles and actions reflecting ways to approach electronic collection data, which is susceptible to being plagiarized, changed, and removed; as well, the researcher's data being misused, which unethical (Sringernyuang, n.d.). This study had no research participants. The main benefit of the study was that it was pre-designed, did not cost much, and was convenient.

Those who may have questions or concerns may refer to Walden University's research policies and guidelines. All of Walden University's research policies and guidelines were adhered to because there was no plagiarizing or removing source data, or interpreting the results based on the need of my study. Findings from the research study cannot be generalized outside of U.S. territory. The public domain databases are opensource and everyone has access on condition that the rules are followed.

\section{Summary}

A qualitative phenomenological design was used for this research study. The elements in this study comprised of secondary data collection; gathering data through secondary analysis; displaying pre-established levels of validity and reliability of the data collection and analysis method. In Chapter 4, I discussed the results of the study including the different typologies, dataset and database collection method, demographics, defining secondary data analysis, the data analysis process for themes and codes, the data analysis for excel workbook, and the summary. 
Chapter 4: Results

This study addressed the paradox between the considerable media attention lone wolf terrorism has received and the lack of examination attributed to the phenomenon. The purpose of the study was to explore the mechanisms and processes that lead individuals to be drawn to or away from an existing radical movement and to act unilaterally and without direction toward violent ends.

\section{Central Research Question and Sub questions}

What are the underlying mechanisms and processes that lead individuals to be drawn to or away from an existing radical movement and to act unilaterally and without direction toward violent ends?

SQ1: What causes an individual to participate in lone wolf terrorism?

SQ2: Are there consistent and significant indicators that can characterize a potential lone wolf actor?

The RAND-MIPT Terrorism Knowledge database and the Global Terrorism Database (GTD) allowed me to gather and analyze data to describe the experiences of the lone wolf terrorist. Both RAND and the GTD have maintained databases on terrorism events dating back to the late 1960s and contain comprehensive information on domestic terrorism. Chapter 4 includes a description of the typologies of lone wolf terrorism, databases used, and data collection. I also present the demographics, data analysis process, results, evidence of trustworthiness, and a summary. 


\section{Typologies}

Numerous typologies illustrate lone wolf terrorism, yet research suggests no illustration can characterize the lone wolf terrorist. Lone wolf contact is at a minimum, if there is any contact at all, with other terrorists or terrorist organizations. These typologies provide contrasting perceptions of the lone wolf phenomenon (Bates, 2012):

1. Extent of radicalization: A common trait of lone wolf terrorists is that they all self-radicalize, but the extent to which it is personal or social through outside influences is unknown.

2. Inspiration: Those who are egoistic or self-centered and think they may be beyond the community and/or an ideological group.

3. Form: The form of lone wolf terrorism may be a lone event or a continuous event.

4. Risk activity: The degree of risk the lone wolf is willing to take.

Pantucci (2011) also proposed a typology that identifies four types of lone wolf terrorists:

1. Loners: Individuals who use Islamist ideology to provide cover for their attempted or carried out actions. Although they assert some devotion to extremist Islamic beliefs, they appear to have no contact at all with terrorist organizations besides the passive information on the Internet.

2. Lone wolves: Individuals, who carry out actions on their own, but demonstrate little contact with terrorist operational extremists.

3. Lone wolf packs: Individual cells of loners who self-radicalized. 
4. Lone attackers: Individuals who operate on their own accord but show a direct link to terrorist organizations.

\section{Databases and Data Collection Method}

Secondary data collection was used in this study. Data collected for the study are available for public use. No data were collected until the final IRB approval was given on June 13, 2017 (IRB approval number 06-13-17-0307965). Data were collected and imported into NVivo from June 21, 2017 through July 23, 2017. No ethical issues arose because there was no plagiarizing or removal of source data. The data records were created to align with this study. Data were collected by exploring RAND and GTD databases for lone wolf terrorist incidents post 9/11 until December of 2016. The search involved lone wolf terrorist incidents in the United States and excluded any group terrorism acts.

An act committed by an individual was marked other to identify a single person as opposed to a group in RAND's database. The GTD used the label individual to designate a single perpetrator. RAND's definition and criteria for incidents to be considered terrorism included the nature of the act, not the identity of the perpetrators or the nature of the cause; key elements included the following:

- violence or the threat of violence,

- calculated to create fear or alarm,

- intended to coerce certain actions,

- motive must include a political objective,

- generally directed at civilian targets, and 
- can be a group or individual (RAND, 2013 p. 1).

For incidents to be included in the GTD, several parameters had to be met:

The GTD defines a terrorist attack as the threatened or actual use of illegal force and violence by a non- state actor to attain a political, economic, religious, or social goal through fear, coercion, or intimidation. In practice, this means to consider an incident for inclusion in the GTD, all three of the following attributes must be present: The incident must be intentional - the result of a conscious calculation on the part of a perpetrator. The incident must entail some level of violence or immediate threat of violence-including property violence, as well as violence against people. The perpetrators of the incidents must be sub-national actors. The database does not include acts of state terrorism. In addition, at least two of the following three criteria must be present for an incident to be included in the GTD: The violent act was aimed at attaining a political, economic, religious, or social goal; The violent act included evidence of an intention to coerce, intimidate, or convey some other message to a larger audience (or audiences) other than the immediate victims; and the violent act was outside the precepts of International Humanitarian Law. (START, 2016, p.1)

The following terms were searched in the databases to garner specific results: homegrown jihadist, lone wolf terrorism, domestic terrorism, loner, lone wolf, homegrown terrorist, lone wolf packs, and individual. 


\section{Codes}

Each record was analyzed in NVivo using text such as perpetrator, nationality of the victim, extremism, loner or lone wolves, the city and state, date, target, property, the mechanisms and ideology derived from the literature, and the indicators that describe the characteristics of the lone wolf terrorist. When I imported and analyzed these documents, these words frequently appeared more than others. For example, the word assailant appeared more often whereas arson appeared less often, as indicated by the font size in the word cloud. Figure 1 illustrates the text search in NVivo.

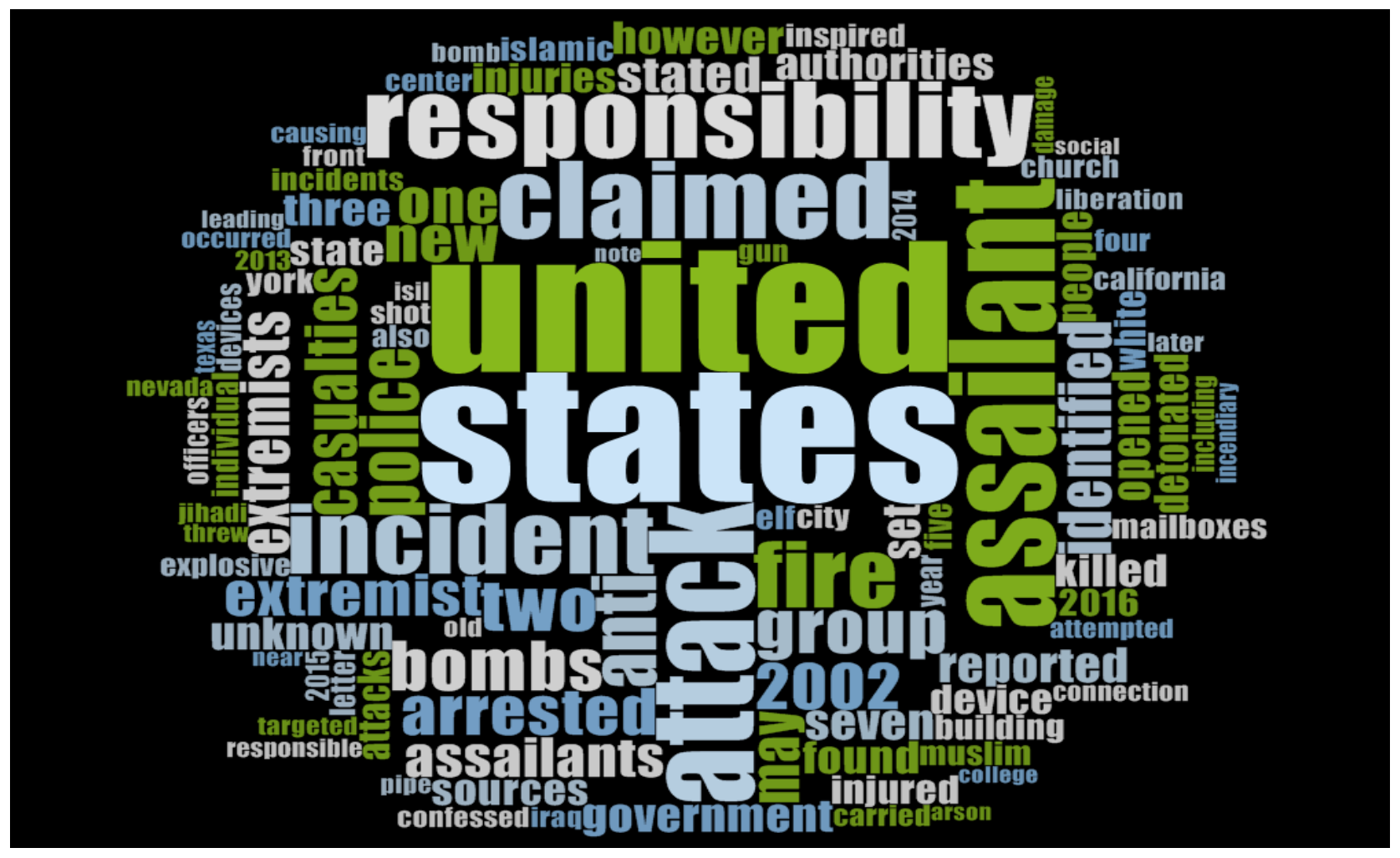

Figure 1. NVivo text search. 


\section{Demographics}

There was a total of 341 terrorist incidents in the RAND and GTD databases from 9/12/01 to 12/31/2016. However, only 177 incidents met the criteria for the study and multiple perpetrators committed multiple acts (see Figure 2). Other incidents were not included because the perpetrator was unknown and the databases recorded incidents until December of 2016. All incidents happened domestically. The perpetrators consisted of 10 females or $6 \%, 131$ males or $74 \%$, and the gender of 31 or $18 \%$ of perpetrators was unknown (see Figure 3). Out of the 177 incidents, 172 of those targets were of U.S. nationality, 1 was Chinese, and 1 Israeli, 1 Mexican, 1 Ireland, and 1 incident had multiple nationalities of people (see Figure 4). The perpetrators were involved in the acts (confessed or physically represented) and incidents were classified as domestic lone wolf terrorists.

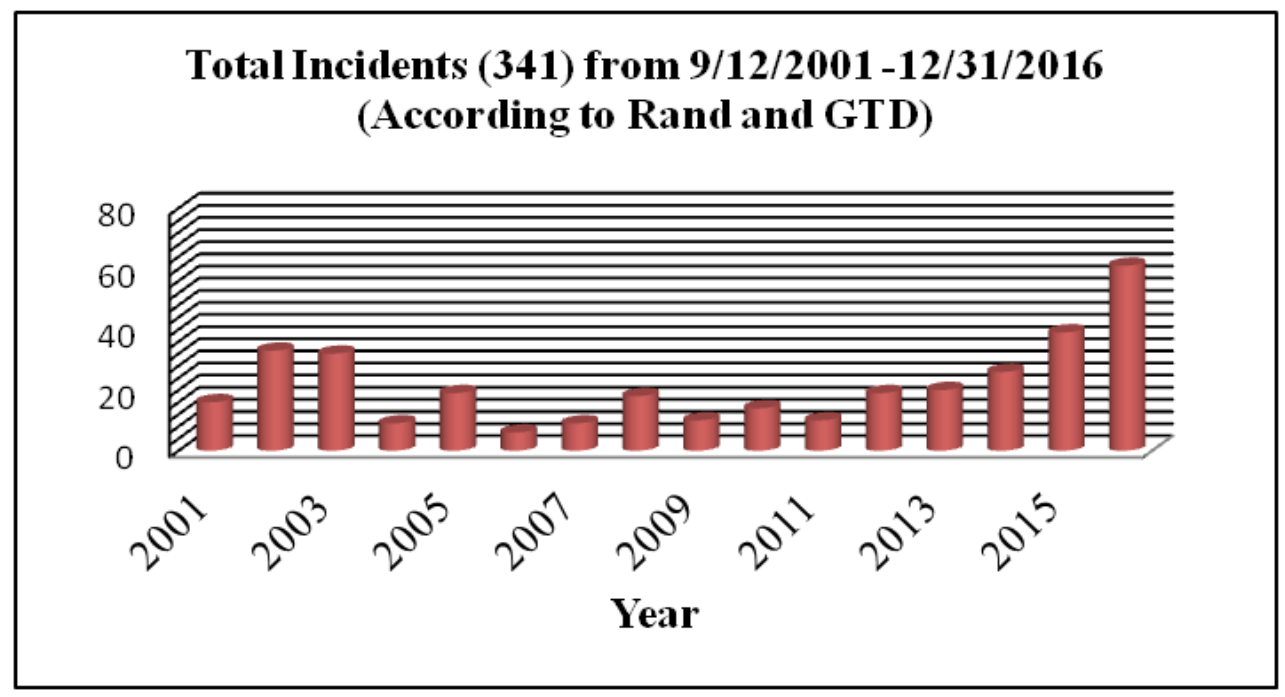

Figure 2. Total incidents (341) from 9/12/2001-12312016. 


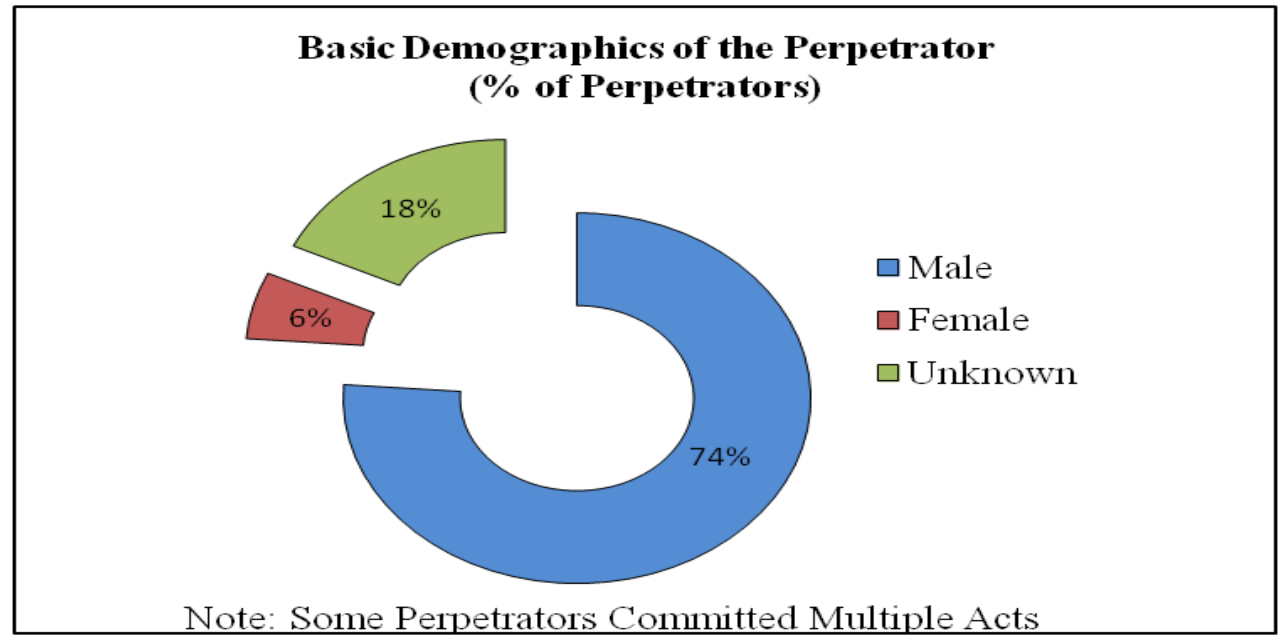

Figure 3. Basic demographics of the perpetrators.

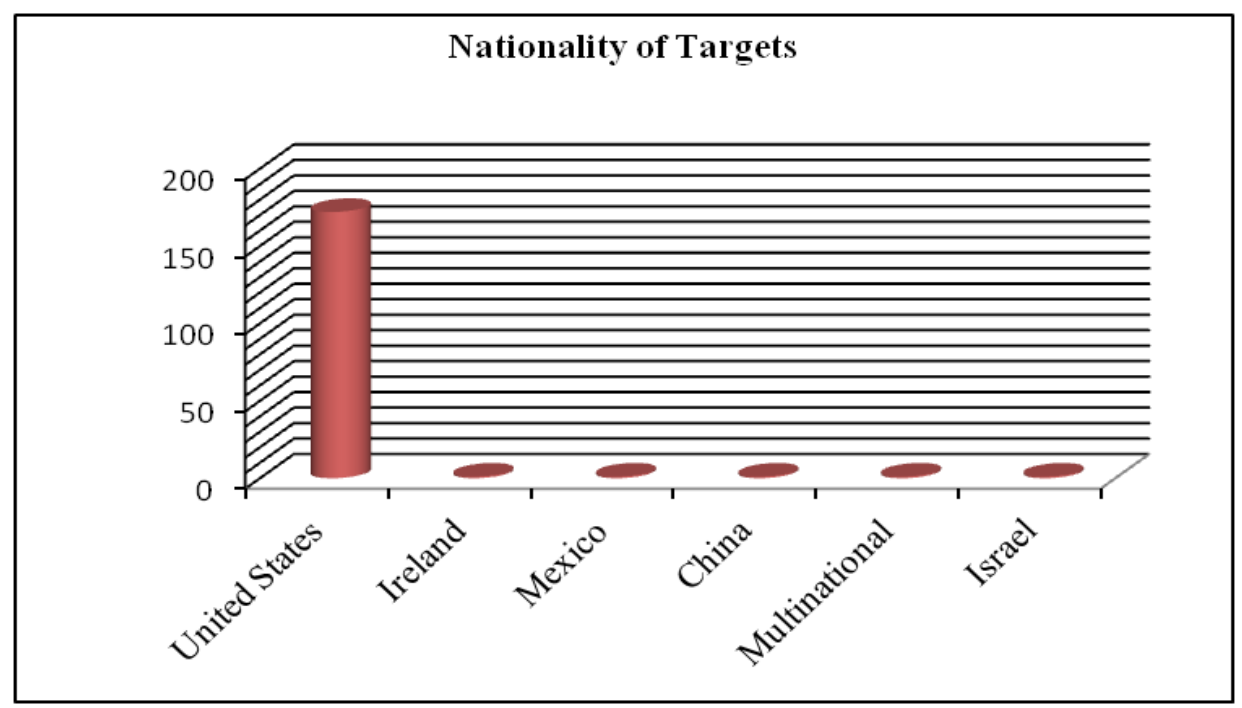

Figure 4. Nationality of targets.

Pantucci's (2011) typology characterized the different types of lone wolves in the study. The individuals were aligned regarding the acts committed and the proper descriptions of the individualized lone wolf. The lone wolves demonstrated some form of contact with operational extremists, yet, their acts were carried out alone and they appeared to be more disturbed individuals seeking consolation in extremist beliefs. The 
loners did not appear to have any contact with operational extremists, and their acts seemed reactive at large to the passive information on the internet.

\section{Data Collection}

I reviewed chapters 1 through 3 focusing more on the research design. After assessing the research design, I used the preceding terms to search the databases resulting in74 total source documents, including testimonies, research reports, reviewed articles, and specific attacks. It took one month to collect the sources data and import it into NVivo. I began developing codes and themes to assist me with categorizing the data. Conducting research prior to data being imported into NVivo helped familiarize my conception of the sources as well as manage my time more efficiently.

\section{Defining Secondary Data Analysis}

Secondary data is the analysis of data that was collected by someone else (Boslaugh, 2007). Secondary data is used to explore alternative research questions from the original data that were collected. The process of coding and classifying themes involved steps, which were formed around my research questions. NVivo software was the primary tool used for coding and manual coding was secondary. This course of action helped examine and evaluate the analysis process, although it prolonged time.

\section{Steps of Secondary Data Analysis}

Portable Document Format (PDF) data were imported from the RAND and GTD databases. Likewise, I duplicated the digital word scripts and imported them into NVivo. When documents were not in PDF, NVivo would not import the document unless they were transcribed in a Word document. After all the sources were imported, I manually 
coded the themes in the interim. I checked off the sources manually to avoid reproducing existing sources. I evaluated several codes and themes that emerged from the central and sub questions using PDF and digital word scripts documents.

\section{Data Analysis Process for Themes and Codes}

The data analysis process was used to support the research questions. This allowed me to gather the appropriate data which permitted me to answer the research questions adequately. After the theme and supporting data was coded I checked it off manually and I then returned to NVivo for more data coding applying the answers accordingly to the themes and foregoing categories. The answers were confirmed to obtain a representative sample.

I then used coded groupings to further materialize the themes. I began with the prior themes that corresponded to each of the research questions: (a) individual mechanisms contribute to likely lone wolf terrorists and their process to a violent end; (b) the phenomenon of the domestic lone wolf terrorist is not limited to a movement. Rather, lone terrorists operate on the fringes of extremist movements, with such loose associations being connected to right-wing ideologies, inspired and fascinated by Islamist ideologies of Arabian Peninsula and The Islamic State of Iraq (AQAP) and Levant (ISIL), and self-developed ideologies facilitating violence based on political, religious, or social change; (c) and these indicators characterized the potential lone wolf terrorist. I replicated the steps for all the themes that emerged for each research question. The mechanisms theme stemmed from the coding answers in the central research question. The theme that lone wolf terrorists operate on the fringes of extremist movements was 
determined based on the coding answers from sub question 1 . The indicators that characterized lone wolves were developed from coding answers to sub question 2.

\section{Data Analysis Process for Excel Workbook}

I applied the same method of coding and analyzing data using the Excel workbook. The process was not detailed due to workbook features. Individually, each category was coded in no order:

- perpetrator;

- nationality of target;

- extremism;

- loner or lone wolves;

- city-state;

- date;

- Ideologies- Rightwing (RW), Islamist (Al Qaida), and self-developed (SD);

- Mechanisms-Personal and political grievance (PPG), Risk and status seeking (RS) and Unfreezing (Unfreezing);

- Indicators- Internet (SM), Fixation (F), Radical expressions (RE);

- Identification (I), and Pseudo spontaneous communication (PSC);

- Target- (People or Property) and;

- Property damage- (Yes or No)

Once the Excel workbook was coded, I compared the data to ensure it was aligned correctly and that it matched information that was imported into NVivo. 


\section{Results}

I began by discussing the themes that corresponds the research questions: (a) individual mechanisms contribute to likely lone wolf terrorists and their process to a violent end; (b) the phenomenon of the domestic lone wolf terrorist is not limited to a movement. Rather, lone terrorists operate on the fringes of extremist movements; (c) and these indicators characterized the potential lone wolf terrorist. I will then provide examples associating with the theme that is being discussed. This will provide a further

outline in for chapter 5 regarding the interpretation of findings, recommendation, and implication of the study.

\section{Central Research Question}

What are the underlying mechanisms and processes that lead individuals to be drawn to or away from an existing radical movement and to act unilaterally and without direction toward violent ends? There are three individual underlying mechanisms and processes that lead individuals to be drawn to or away from an existing radical movement: personal and political grievance, risk-and-status seeking, and unfreezing.

Primary experienced mechanism. Personal and political grievance is a combination between the two and is the primary experienced mechanism of individual radicalization. Individuals believe some sort of injustice has occurred either to them or to society and they tend to form their own beliefs and ideologies. This materialized in 168 out of 177 incidents or $95 \%$ and was inferred from three experiences (see Figure 5). 


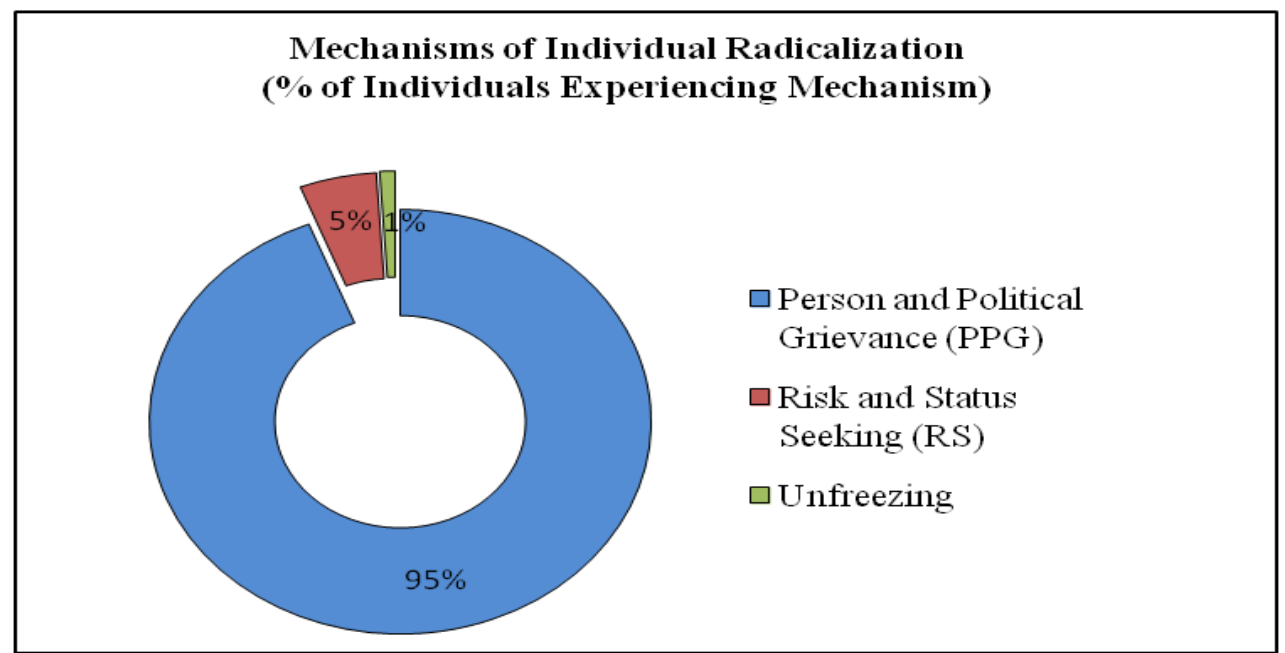

Figure 5. Mechanisms of individual radicalization.

Overall, the primary mechanisms that lead individuals to a violent end are one of the most significant developments of the study. Personal and political grievance appeared in numerous forms and was shown in ways such as individuals believing harm was inflicted upon them individually or to society, assuming the environment or humanity was being destroyed, and feeling like policies, laws, and/or regulations were unjust. Here are different examples of personal and or political grievance being demonstrated through violent acts:

An assailant sent a message via Twitter to Kurt Eichenwald, a Newsweek journalist, in Dallas, Texas, United States. The message contained the text "you deserve a seizure for your posts" and a GIF image of a strobe. Edgar M. Welch stated that he targeted Comet Ping Pong because he suspected the human trafficking of children was occurring at the restaurant. Lakeem Keon Scott claimed responsibility for the incident and stated that he carried out the attack because he was upset with the deaths of African Americans by authorities in 
Louisiana and Minnesota. Sanford stated that he targeted Trump because he believed "somebody had to stand up for America". (GTD and RAND, 2017, p.1)

Others believed harm was inflicted upon them individually or to society:

Authorities arrested Dana Ericson, who confessed to the attack, self-identified as a white supremacist, and indicated that his goal was ethnic cleansing. In court, Ericson stated that he was trying to start a revolution. Robert Lewis Dear claimed responsibility for the incident and stated that he was a "warrior for the babies. Rasheed Abdul Aziz told the pastor that he had been sent by "Allah" to slay infidels. Hapner confessed to the arson and claimed that he was trying to "eradicate pornography." (GTD and RAND, 2017, p.1)

For instance, when individuals assumed the environment or humanity was been destroyed, random bombings took place as an example:

At approximately 3:15 a.m. local time, seven firebombs were detonated at a newly constructed apartment complex in Sutter Creek, California, United States. Six of the firebombs were extinguished by the sprinkler system, but the seventh firebomb exploded and caused approximately $\$ 50,000$ worth of damage to the complex, although no casualties resulted from this attack. The group Earth Liberation Front (ELF) claimed responsibility for this attack and subsequently three individuals were arrested and charged. Similarly, an assailant attempted to bomb a natural gas pipeline in Plano, Texas, United States and was critically injured. Sources note that Anson Chi identified as part of the anti-government Sovereign Citizen movement. (GTD and RAND, 2017, p.1) 
Some of the individuals felt like policies, laws, and/or regulations were unjust. Case in point:

A letter containing ricin was mailed to the Director of Mayors against Illegal Guns, Mark Glaze, in Washington, District of Columbia, United States. The letter warned of future attacks if Glaze and other gun control advocates pursued legislation to limit gun ownership. Joseph Stack flew his private plane into the IRS building. He had problems with the IRS in the past and believed violence was the only answer. Dwight Watson, a tobacco farmer from North Carolina, drove a tractor through the Constitution Gardens in Washington D.C., United States. Watson believed that the tobacco policies of the United States government were unfair to the tobacco farmer and he was trying to bring nationwide attention to the policies that he maintained ruined him financially. (GTD and RAND, 2017, p.1)

Second experience mechanism. Risk-and-status seeking individuals were devoted and inspired and/or fascinated by the teachings of Anwar Awlaki's, Abu Muhammad al Adnani, and/or Osama bin Laden under al-Qaeda in the Arabian Peninsula or The Islamic State of Iraq and Levant (ISIL) for whom violence may seem the best path for respect. This materialized in 8 out of 177 incidents or $5 \%$ and was the second most experienced mechanism in the study (see Figure 5).

The risk-and-status seeking individual mechanism of radicalization was demonstrated in numerous of cases. For instance:

Security forces discovered and defused an explosive device in the Chelsea neighborhood of Manhattan, New York City, United States. The device was 
discovered several blocks away from an explosion that occurred earlier the same day. Ahmad Khan Rahami claimed responsibility for this incident and three similar bombings that occurred between September 17 and September 18, 2016 in New York and New Jersey. Sources suspected that Rahami may have been inspired by Abu Muhammad al Adnani, a spokesperson for the Islamic State of Iraq and the Levant (ISIL). Sources also noted that Rahami admired Osama bin Laden and Anwar al-Awlaki in his journal. (GTD and RAND, 2017, p.1)

An assailant shot and killed John Bailey Clark Jr. and buried him in a grave outside his residence in Morganton, North Carolina, United States:

No group claimed responsibility for the incident; however, sources attributed the attack to an individual, identified as Justin Nojan Sullivan. Sources posited that Sullivan, who was arrested in connection to the attack, targeted John Bailey Clark Jr. to steal money from the victim, so he could purchase a rifle to carry out an Islamic State of Iraq and the Levant (ISIL) inspired attack. (GTD and RAND, 2017, p.1)

Shots were fired at the Pentagon located in Arlington, Virginia, United States:

Security reported hearing between five and seven shots fired at the building at 4:55 am. No one was injured in the attack, but two windows were damaged. Yonathan Melaku, a Marine Corps reservist, was arrested on June 17, 2011, for an unrelated incident but was charged on June 21, 2011, for the Pentagon shooting and several other similar attacks in the area, including two shootings on the National Museum of the Marine Corps, and two at Marine Corps and Coast Guard 
recruiting stations. Sources report that Melaku was fascinated by al-Qaeda, but did not claim to be a member of the organization. (GTD and RAND, 2017, p.1) Third experience mechanism. Unfreezing is a personal crisis such as a mental disorder or illness that leaves an individual with less to lose and in search of new directions. This happened once out of the 177 incidents or $1 \%$ and was the least experienced mechanism (see Figure 5). One eccentric perpetrator left a note containing: A small pipe bomb put in a foam box was found in a Philadelphia, Pennsylvania, United States mailbox. Police safely detonated the device, which was packed with nails, and no one was hurt. The bomb had a note that stated, "Free Palestine" and also reportedly made some reference to al-Qaeda. A 53-year-old Philadelphia man, Preston Lit, who had no connections with al-Qaeda or any other terrorist group, was charged with threatening to use explosives. He had a criminal past and reportedly suffered from bi-polar disorder and other mental sicknesses. (GTD and RAND, 2017, p.1)

Sources noted the existence of mental illness should not be an indicator of limited rationality or reduced ability to plan and conduct an attack. The correlation of mental illness with lone wolf terrorists should not, therefore, be considered an indicator that a lone wolf terrorist presents a reduced threat; rather the findings are a further contribution toward understanding the phenomenon (GTD and RAND, 2017, p.1).

\section{Sub question 1}

What causes an individual to participate in lone wolf terrorism? There is no single profile of a lone wolf terrorist. As was stated earlier, usually it is combination between 
personal and political grievances. It is extremely difficult to differentiate between individuals using terrorism because of personal and political grievances and those that are committed to an ideology. Sub question 1: includes right-wing ideologies (a); selfdeveloped ideologies (b); and Islamist ideologies (c).

Primary experienced ideologies. The primary experienced ideology that developed from this study was right-wing ideology. Right-wing ideology refers to a person or group who holds extreme or fanatical political or religious views, especially one who resorts to or advocates extreme actions without organizational assistance. This occurred in 78 out 177 incidents, or $44 \%$ and was inferred from 13 right-wing extremist ideological movements (see Figure 6).

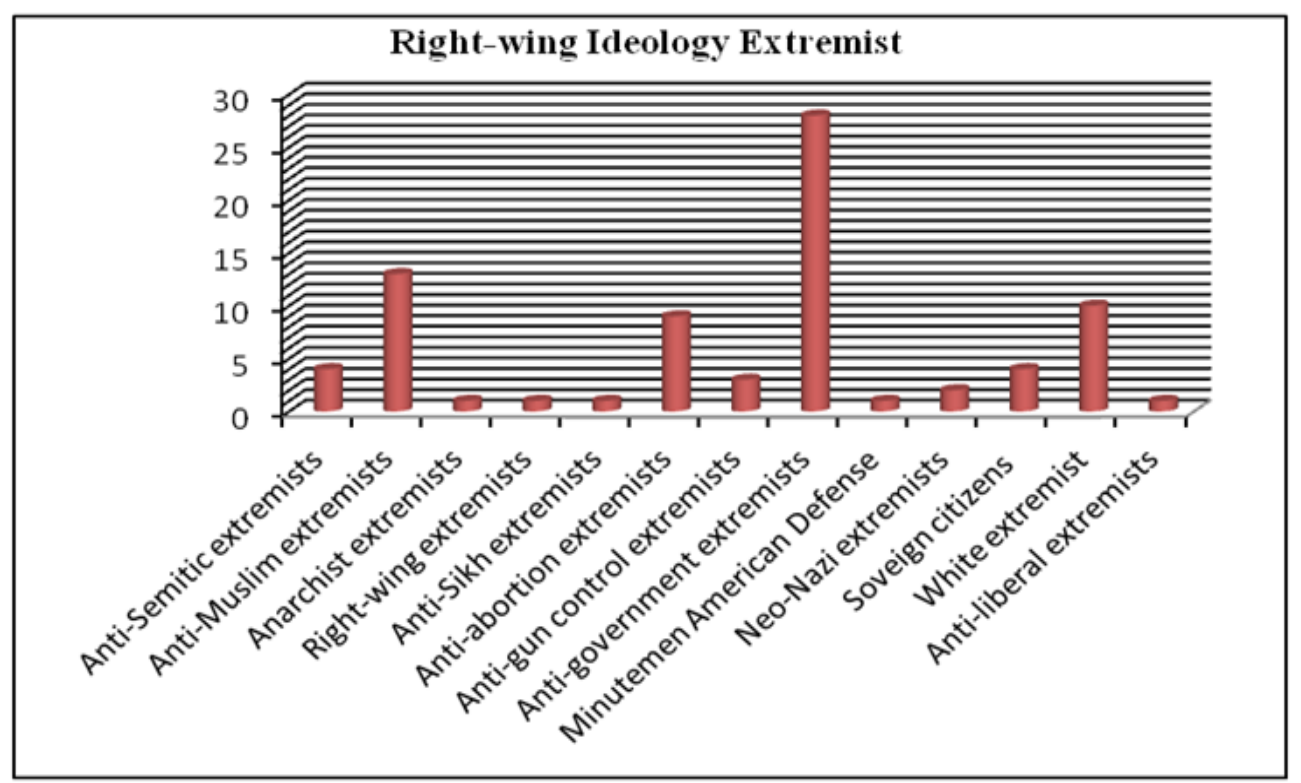

Figure 6. Right-wing ideology extremists.

Largely for sub research question 1 and the second significant theme, domestic lone wolf terrorists are not limited to a movement; rather, lone terrorists operate on the 
fringes of extremist movements. This was the most profound, volatile, and rebellious form of terrorism associated with a lone wolf in this study. But, only four will be discussed because they had eight or more incidents: anti-government extremists; antiMuslim extremists; white extremists; and anti-abortion extremists.

Anti-government right-wing extremist sees the government as the enemy and use violence as a result.

For example:

An assailant opened fire on a federal courthouse in Austin, Texas, United States. This was one of three attacks carried out by the assailant that targeted government and security buildings in the city. Sources suspected that anti-government and anti-immigration sentiments fueled the incidents. (GTD and RAND, 2017, p.1)

The anti-Muslim extremist movement is a new phenomenon. Many of these attacks begin post 9/11 and extreme aggression is shown toward Muslims individuals. The perpetrators who oppose Muslims see Islam as the fundamental reason for their inherent behavior. For instance:

An assailant assaulted a Muslim store clerk at Fatima Food Mart in Queens, New York City, United States. The clerk was injured in the attack. The assailant, identified as Piro Kolvani, said, "I kill Muslims" during the attack and was later arrested.” (GTD and RAND, 2017, p.1)

White supremacists believe they are superior to all other races and some perpetrators demonstrated their experience in the following ways: 
On Wednesday afternoon at approximately 12:40, in Washington, District of Columbia., United States, an assailant armed with a rifle entered the National Holocaust Memorial Museum and fired upon civilians, killing one security guard, Stephen Tyrone, and injuring an unknown number of civilians. The shooter was wounded critically in the attack and identified as white supremacist, James W. von Brunn. Officials believe the attack may have been politically motivated. (GTD and RAND, 2017, p.1)

The anti-abortion movements are individuals or groups who believe abortion is unethical and that violence is justified against people and establishments providing abortion services. These begin as counter-movements and then they developed into acts such as the following:

An assailant opened fire on a Planned Parenthood clinic and held an unknown number of people hostage for five hours in Colorado Springs, Colorado, United States. At least three people were killed and nine other people were wounded in the assault. An individual, identified as Robert Lewis Dear, claimed responsibility for the incident and stated that he was a "warrior for the babies." (GTD and RAND, 2017, p.1)

Second experienced ideologies (single-issue protest). Self-developed ideology (singleissue protest) is when the individual takes steps in advocating or adopting an extremist belief to facilitate ideologically-based violence to advance political, religious, or social change. This second experienced ideology materialized from sub question 1 and 
materialized in 67 out 177 incidents or 38\% (see Figure 7), and was led by unknown extremist and the Earth Liberation Front.

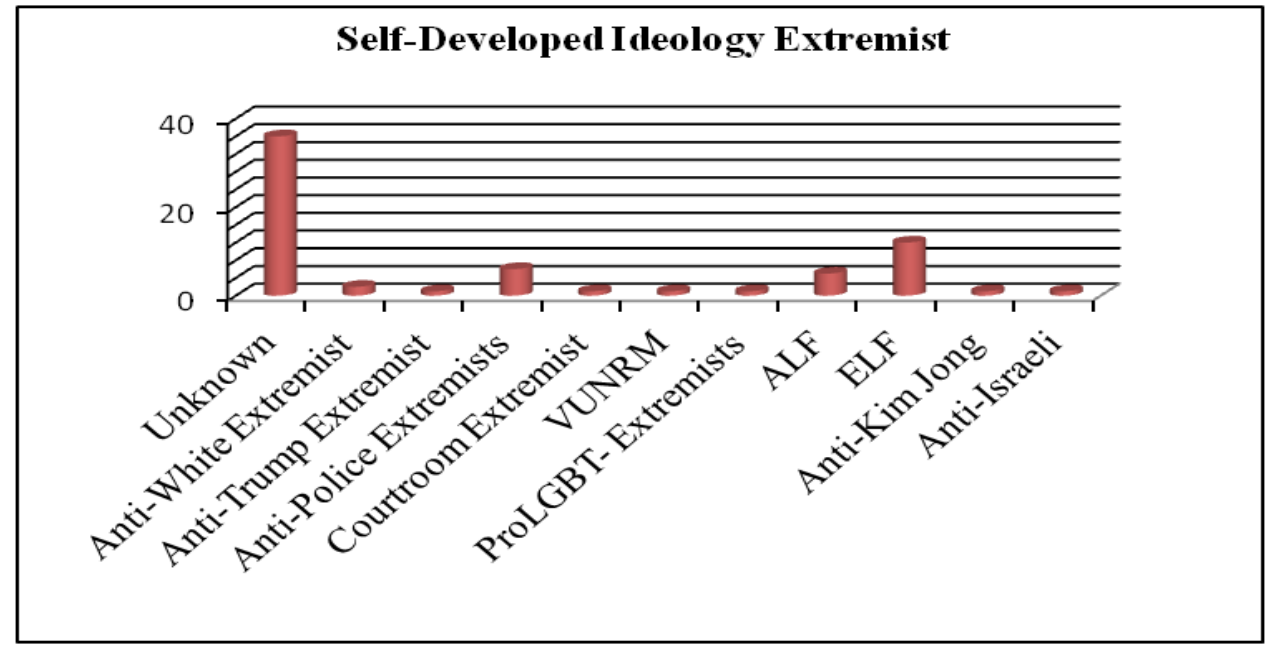

Figure 7. Self-developed ideology extremists.

When trying to illustrate the lone wolf terrorist, it is difficult because often pieces they do not come with warning signs. Their extremism, if any exists, appears to be unknown. For example:

An assailant set fire to a residence in Endicott, New York, United States. The offender placed gasoline-filled cans throughout the house as obstacles and spraypainted the anti-police message "lie with pigs, fry like bacon" on an exterior wall of the house before starting the blaze. The family sleeping inside the house escaped, and no injuries were reported. No group claimed responsibility; however, authorities arrested and charged firefighter Jason T. Stokes with starting the fire at his own house." (GTD and RAND, 2017, p.1) 
The Earth Liberation Front (ELF) uses "economic" sabotage and guerilla warfare to stop the exploitation and destruction of the environment. In 2001, the ELF was classified as the top domestic terror threat to the United States by the Federal Bureau of Investigations. These autonomous individuals continue to conduct attacks every so often. For instance:

Grant Barnes, suspected affiliated with the Earth Liberation Front (ELF), planted an incendiary device under a parked 1996 Chevrolet Tahoe in the driveway of Josh and Jennifer Rudolph's home in the Cherry Creek neighborhood of Denver, Colorado in the United States. The SUV sustained heavy fire damage, but there were no casualties in the incident. Two more devices were discovered, targeting other SUVs in the area on this day. These were three in a series of seven firebombs which Barnes planted in the Cherry Creek area, targeting SUVs over the course of four days. Barnes was arrested on March 22, 2007, indicted, and pled guilty in July 2007, and sentenced to 12 years in prison. (GTD and RAND, 2017, p.1)

Third experienced ideologies. Individuals used Islamist ideologies that were inspirational, fascinating, and devoted to the teachings of Abu Muhammad al Adnani, Anwar Awlaki's, in Osama bin Laden in the Arabian Peninsula (AQAP) and The Islamic State of Iraq and Levant (ISIL) to commit violent acts. The third experienced ideology materialized as well from sub question 1(see Figure 8), and had 32 occurrences out 177 incidents, or $18 \%$. The two extremisms that materialized the most from Islamist ideology were Jihadi-inspired extremists and Muslim extremists. 


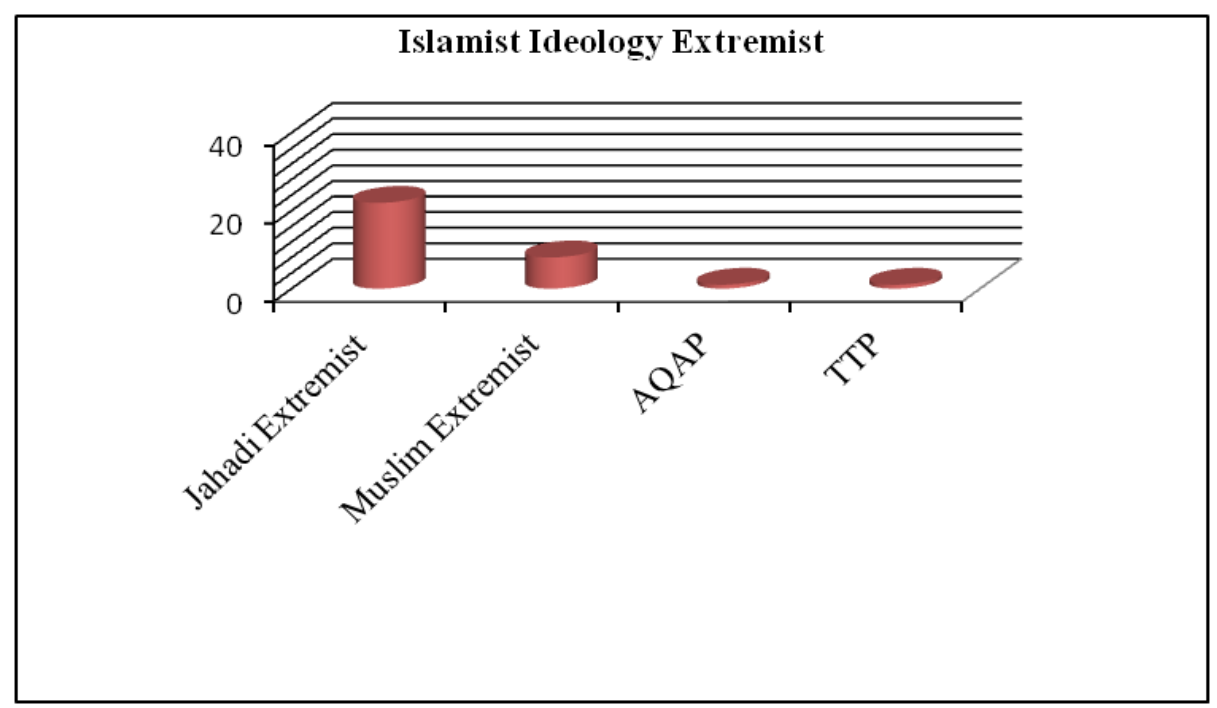

Figure 8. Islamist ideology extremists.

Jihadi-inspired extremists refer to Islamic extremism occurring within the United States. Islamic extremism is adherence to a fundamentalist interpretation of Islam, potentially using violence to achieve political goals. Ali Muhammad Brown was one of the:

assailants that shot and killed Brendan Tevlin as he was stopped at a traffic signal in West Orange, New Jersey, United States. Police later arrested three suspects, including Ali Muhammad Brown, in connection with the case. Authorities claim that Brown committed the act to punish the United States for its involvement in Iraq and Afghanistan. Brown has been indicted on murder charges in connection with two separate attacks that occurred earlier in the year in Skywalk and Seattle, which are both located in the state of Washington. (GTD and RAND, 2017, p.1) 
Muslim extremists perceive any form of Islam that opposes "democracy," the rule of law, individual liberty, and mutual respect and tolerance of different faiths and beliefs. This was identified when:

An assailant opened fire on a military recruiting office in Chattanooga, Tennessee, United States. There were no reported casualties resulting from the assault. This was one of two attacks carried out by the same assailant within a short period of time; after targeting the office, the assailant attacked a military training center in the area. No group claimed responsibility for the incidents; however, the assailant was later identified as Mohammad Youssuf Abdulazeez. (GTD and RAND, 2017, p.1)

\section{Sub question 2}

Are there consistent and significant indicators that can characterize a potential lone wolf actor? In characterizing the lone wolf terrorist, there are several indicators: gender, the internet, radical expressions, pseudo spontaneous communication, fixation, and identification. However, only pseudo spontaneous communication, fixation, identification, and radical expressions were discussed because they had eight or more incidents.

Primary experienced indicator. Pseudo spontaneous communication involves the intentional and strategic manipulation of some formal display(s). Individuals will attack a mosque or another symbolic display to express their personal and or political grievance towards an object or person, sending a message to infuriate others. Pseudo spontaneous communication materialized in 71 out of 177 incidents or $40 \%$. This emerged from sub question 2 (see Figure 9). 


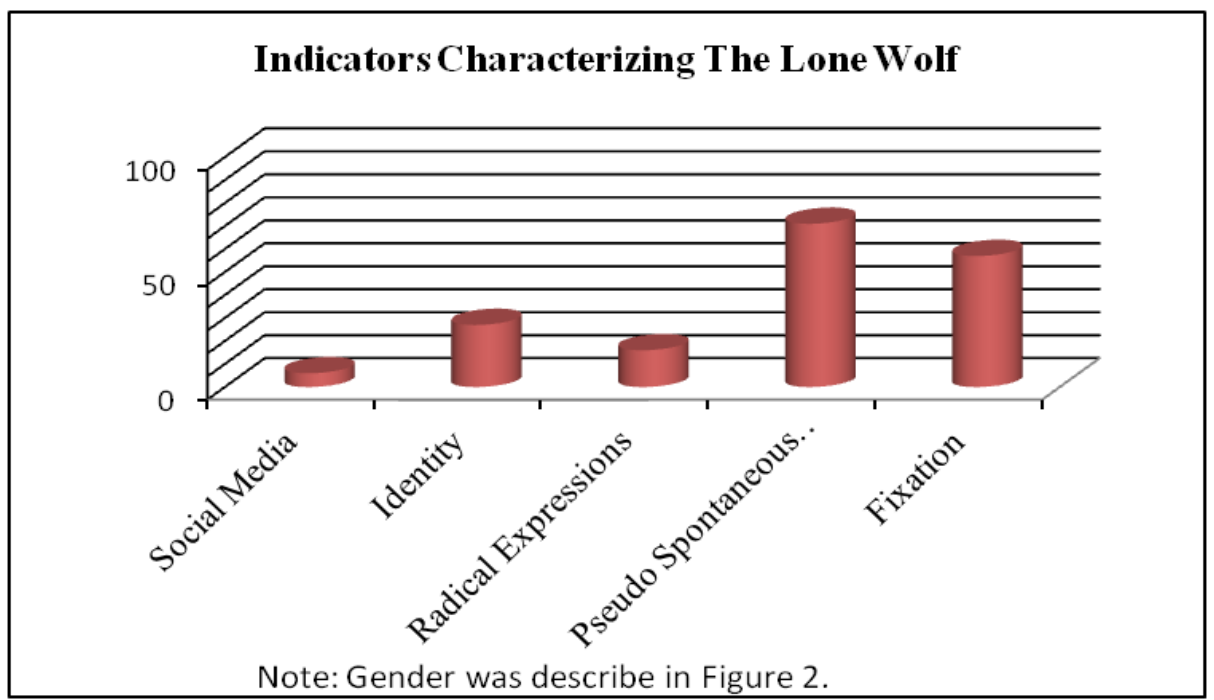

Figure 9. Indicators characterizing the lone wolf.

Overall, pseudo spontaneous communication was shown to be a consistent indicator of the lone wolf. The incidents are an important way for individuals to get their message across and contain important information from the "individual" perspective. This theme is defined by the nature of the act, not the identity of the perpetrator or the nature of the cause, and was reflected in the following incidents below:

An assailant set fire to the Islamic Center mosque in Fort Pierce, Florida, United States. There were no reported casualties in the attack. Joseph Michael Schreiber was arrested and claimed responsibility for the incident. An explosive device detonated in a Rainbow Times newspaper box in Salem, Massachusetts, United States. There were no reported casualties in the blast. No group claimed responsibility for the incident. (GTD and RAND, 2017, p.1) 
Second experienced indicator. Fixation is being obsessed with a person or cause and it was subsequent to pseudo spontaneous communication with 57 out 177 incidents, or 32\% (see Figure 9). These incidents tend to play out in numerous ways and they seem to be focused on societal issues like the two-described underneath:

An unknown anti-police extremist group claimed responsibility for the incident in a note left at the scene and stated, "Black Lives Matter" while also mentioning Alton Sterling and Philando Castile.” An assailant also opened fire on New York City Police Department officers while they were sitting in their vehicle in Bedford-Stuyvesant neighborhood, Brooklyn, New York City, United States. Officers Wenjian Liu and Rafael Ramos were killed in the attack. The assailant, identified as Ismaaiyl Brinsley, claimed responsibility and stated that the attack was carried out to avenge the deaths of Michael Brown and Eric Garner at the hands of the authorities.

Third experienced indicator. Identification is the willingness of the attacker to commit violence as an agent of a belief system. This occurred in 27 out 177 incidents, or $15 \%$ (see Figure 9). Because identification is an indicator that leads individuals to violent ends, this suggests the individual's behavior is driven by components of social identity like in such cases below:

Three assailants armed with knives attacked a group of Hispanic teenagers playing soccer at Stephen Sorensen Park in Lake Los Angeles, California, United States. At least two people suffered minor injuries in the assault. The three assailants, identified as Ian Justine Plankey, Richard Lawrence Daulton, and 
Kevin Matthew Stewart, were arrested following the incident. During the attack, they shouted white supremacist statements and racial slurs, including "Heil Hitler, AV Skins." Furthermore, an assailant attacked a police patrol with a hatchet in Queens, New York City, United States. The assailant was killed and two officers and a bystander were wounded in the attack. Zale Thompson, a convert to Islam, was responsible for the incident. (GTD and RAND, 2017, p.1)

Fourth experienced indicator. Individuals frequently use radical expressions in social media, blog postings, and alternate forums to express their personal and or political beliefs. This materialized under sub question 2, showing 16 out of 177 incidents, or $9 \%$ (see Figure 9). For example:

Sources identified the assailant as Gavin Long and while his specific motive is unknown, Long's social media presence indicated that the attack may have been related to racial tensions. On social media, the assailants expressed radical views and decried the federal government, taxes, anti-gun laws, and demanded a revolution. In another attack, both assailants identified as Syed Rizwan Farook and Tashfeen Malik, fled the scene but were located and killed in a shootout with police the later the same day. Tashfeen malik pledged allegiance to the leader of the Islamic State of Iraq and the Levant (ISIL) on social media on the day of the attack. ISIL referenced the assailants as 'soldiers of the caliphate.' However, sources did not report a connection between the assailants and ISIL. 


\section{Evidence of Trustworthiness}

Trustworthiness consisted of several components in this study: (a) Credibility: ethical issues and principles were adhered to because all source document data remained the primary source; (b) Transferability: is trustworthy because data were imported directly into NVivo precisely; (c) Dependability: the dependability of the study materialized from 74 sources, which, in turn, produced 177 perpetrators from testimonies, research reports, and reviewed articles; (d) and Intra Coder-Reliability: an intra-coder technique was a more effective way to convey and transform the personal experience of individuals from their personal perspective, challenging fundamental beliefs (Creswell, 2009).

\section{Credibility}

As for the credibility of my phenomenological research study, all potential ethical issues and principles were adhered to because all the source document data remained the primary source, and there was no plagiarizing, copying, or removing of the data. I used the research data to examine a correlation primary and secondary data to carrying out the research. The purpose was to ensure the studies questions were aligned with my research questions, and that the primary data collection and analytic techniques were applied to the secondary analysis (Northern Arizona University, 2013). Secondary data helped create my research design and it provided an outline to which secondary data analysis was compared. 


\section{Transferability}

Transferability is conveyable because data were imported directly into NVivo precisely. The data gathered from the source documents were coded and schematized. Because of the substantial amount of information available, secondary data analysis displayed pre-established levels of validity and reliability, which do not have to be examined again by the researcher if he or she has plans to re-use the information (Sringernyuang, n.d.).

\section{Dependability}

The dependability of the study materialized from 74 sources, which, in turn, produced 177 perpetrators from testimonies, research reports, and review articles that met stringent criteria for it to be categorized as lone wolf terrorism in this study. This study had no research participants. The main benefit of the study could assist national security officials and intelligence agencies in identifying lone wolf individuals, weighing the actual threat versus the perception, developing better counterterrorism strategies for the lone wolf phenomenon. Programs like NVivo are commonly used and make data more manageable to analyze, record, and edit. The data was manually coded in addition so that I was comfortable engaging with the data.

\section{Intra-Coder Reliability}

An intra-coder technique was a more effective way to convey and transform the personal experience of individuals into their personal perspective, challenging fundamental beliefs (Creswell, 2009). Most importantly, this dimension to the research study enabled me to use it as a foundation for a real-world theory, allowing it to advise, 
assist, or contest course of action (McNabb, 2010). Although data were limited and researchers and scholars talk about their perception of the lone wolf terrorist through group terrorism studies, studies that disassociate the lone wolf from the group phenomenon can define their exact experiences, obstacles, and benefits.

\section{Summary}

The objective of chapter 4 was to provide analysis and exploration of qualitative data with 177 incidents of lone wolf incidents in the United States post 9/11. The results were discussed in detail through the lenses of the perpetrators for which the lone wolf actions are set in motion, ultimately leading to a violent end. A qualitative phenomenological design was used via secondary analytical method.

The findings support that there are three individual-level underlying mechanisms and processes (personal and political grievance, risk and status seeking, unfreezing) that lead individuals to be drawn to or away from an existing radical movement and to act unilaterally and without direction toward violent ends. The phenomenon of the domestic lone wolf terrorist is not limited to a movement. Rather, lone terrorists operate on the fringes of extremist movements, with such loose associations being connected to rightwing ideologies, inspired and fascinated by Islamist ideologies of Arabian Peninsula and The Islamic State of Iraq (AQAP) and Levant (ISIL), and self-developed ideologies facilitating violence based on political, religious, or social change. There were several indicators to characterize the lone wolf terrorist: gender, the internet, fixation, identification, and pseudo spontaneous communication. In chapter 5 I advance the discussion, conclusion, and give recommendations. 
Chapter 5: Discussion, Conclusions, and Recommendations

The purpose of this study was to explore the lone wolf phenomenon apart from other types of political violence and terrorism using the RAND-MIPT Terrorism Knowledge Base and the Global Terrorism Database. Data were collected for this study through the gathering of testimonies, research reports, reviewed articles, and specified attacks. This study was guided by the central research question: What are the underlying mechanisms and processes that lead individuals to be drawn to or away from an existing radical movement and to act unilaterally and without direction toward violent ends? Additionally, two sub questions were explored: What causes an individual to participate in lone wolf terrorism? Are there consistent and significant indicators that can characterize a potential lone wolf actor?

The three main themes addressed the three research questions in the study. First, results indicated that personal and political grievance, risk and status seeking, and unfreezing were the major mechanisms and processes of lone wolf terrorism. Second, right-wing ideology extremist movements, Islamist ideology extremist movements, and self-developed ideology extremist movements were the primary causes of domestic terrorism. Third, men were more likely to be involved in lone wolf incidents using formal displays, fixation, and venting radical expressions.

The central research question was answered via the results from the primary question and the sub questions. Regarding how mechanisms and processes have influenced the domestic terrorist, a central finding indicated that there was no single profile to characterize the domestic lone wolf. Instead, personal and group grievance, as 
well as a self-developed ideology, allows the domestic terrorist to lie dormant and undetected. However, although grievances are a part of the process, gender is a major indicator. The findings indicated that domestic lone wolf terrorist acts are not always large, yet they cause considerable damage to the government and the populace.

\section{Interpretation of Findings}

I conducted a phenomenological study to explore, identify, and describe the experiences of lone wolf terrorists through 177 domestic lone wolf terrorist incidents. The study addressed the paradox between the considerable media attention lone wolf terrorism has received and the lack of formal study of the phenomenon. The study was designed to answer one central research question and two sub questions. This section provides an interpretation of the findings for the central research question, Sub question 1 , and Sub question 2.

\section{Central Research Question}

This study was guided by the central research question: What are the underlying mechanisms and processes that lead individuals to be drawn to or away from an existing radical movement and to act unilaterally and without direction toward violent ends? The findings suggested that the underlying mechanisms and processes of the domestic lone wolf terrorist acting alone are not the same as thinking autonomously. The individual's mental process must be oppressed or he or she must be grieving personally or politically. Lone wolf terrorists are risk- and status-seeking individuals who are inspired and/or fascinated by different ideologies for which violence may seem the best path to gain respect. Mental illness may or may not play a role in the act, and the disconnection leaves 
an individual with less to lose and in search of new directions. This allows the domestic terrorist to lie dormant and undetected. However, gender does play a major role.

Personal and political grievances can transfix the lone wolf terrorist's thought process. For instance, the thought process of an anti-Muslim extremist believing that Islam is the inherent cause for their acts and a Muslim extremist believing that the wars are an attack on Islam weighs heavily upon them. Anti-Muslim extremist perspectives on Islam and Muslim extremist perspectives on the wars were created individually, but they did not manifest autonomously. When individuals act alone and are motivated by a larger movement, they fill a personal and/or social-political void. The effects of personal and political grievance be a precursor or mechanism to a violent end.

Risk- and status-seeking individuals who see violence as the best path to effect change align their beliefs to match their actions. The actions are believed to be justified, and it is the irrational thought-provoking process that ultimately leads to violent ends. Lone wolf terrorists seek respect and status, and they will risk everything to achieve prominence even if leads to a violent end. Lone wolves identify with certain movements and feel that the act represents the movement they are associating themselves with. The risk- and status-seeking process is another form of mechanism.

The unfreezing process cannot be simplified to a mental disconnect. In the event, the lone wolf must commit the act. The media likes to attribute terrorist acts to some type of mental illness. Individuals dealing with a personal crisis or who have a mental illness are more likely to be portrayed as terrorist although one percent of these individual are lone wolf terrorist. During the process of searching for a new direction, these individuals 
attached themselves to a movement or to another external component or outside influence. The movement or external component is a mechanism that forms in the process.

The results from the central research question were consistent with the Global Terrorism Trend analysis report. In the report, Pajunen (2017) stated The process of individual transformation into a lone wolf terrorist contains an immeasurable number of interacting factors. These factors differ from individual to individual as psychologies and experiences are never the same between two individuals. However, a commonality between every single lone wolf terrorist is that they underwent a process. (p. 12)

Very few individuals radicalize to the point of violent endings; to take the thought and transform it into action is difficult, and the need to avoid being caught it is even harder because they do not have assistance (Pantucci, Ellis, \& Chaplais, 2017).

There is a consensus in terrorism literature that it is impossible to profile lone wolf terrorists. When looking at any large database of perpetrators, the conclusion is often that they are drawn from across society, age group, and even gender. Nonetheless, accepting this limitation, important insights can be gained from this literature (Pantucci et al., 2017).

\section{Sub question 1}

Sub question 1 was as follows: What causes an individual to participate in lone wolf terrorism? The findings of Sub question 1 indicated that extremist movements and ideologies are a major cause of individuals participating in lone wolf terrorism. 
Individuals are different, and so are the forms of movements. The rise of the selfdeveloped lone wolf has created a problem that continues to puzzle national security officials. Right-wing and Islamist extremist ideologies are common causes among the self-developed lone wolf in the leaderless resistance theory.

The theme and experiences that materialized from Sub question 1 included lone wolf terrorists operating on the fringes of extremist movements with loose associations to right-wing ideologies, including individuals inspired and fascinated by Islamist ideologies of the Arabian Peninsula (AQAP) and The Islamic State of Iraq (ISIL), and those with self-developed ideologies who commit violence based on political, religious, or social beliefs. Lone wolf terrorist seems to have reemerged in the later part of the $20^{\text {th }}$ century by right-wing, Islamic, and other types of extremists. Unlike a terrorist group, lone wolves are hard to counter. Though they may not have organizational support, their chances of being caught are less risky and their liabilities decrease than if they were in a group (Bates, 2012). Bates (2012) also mentioned that "Though lone wolf terrorists selfradicalized, their motivation may not always be political or religious. Lone wolf terrorists may be motivated by personal agendas in response to some real or perceived organizational event" (p.4).

\section{Sub question 2}

Sub question 2 was as follows: Are there consistent and significant indicators that can characterize a potential lone wolf actor? The findings of sub question 2 consist of several indicators: gender, the internet, radical expressions, fixation, identification, and pseudo spontaneous communication. There are signs for help before violence erupts, yet, 
the signs are overlooked until after the act has occurred. The "See Something, Say Something" media campaign is an important part in the fight against lone wolf terrorism. The theme that materialized the most in what significant indicators can characterize a lone wolf terrorist show pseudo spontaneous communication as the major indicator for sub question 2 .

Homeland Security Secretary Janet Napolitano cautioned that lone wolf terrorism may be rising sooner than later. The current attacks are on a smaller scale now, but, with the rise of lone wolf activities, it is only a matter of time before the big boom occurs. Therefore, when individuals spontaneously act, they are most difficult to prevent and there is nothing to intercept communication wise (Simon, 2013).

The day of the Boston bombings was not the first time the FBI had heard of Tamerlan Tsarnaev. A "foreign government" had asked the bureau to investigate him early in 2011, warning that he was a follower of radical Islam. In the case of Hasan, the warnings were also there. Hasan made statements justifying homicide bombings, spewed anti-American hatred, and reached out to al-Qaeda (Simon, 2013, p.1). Where the most attention, help, and funding is needed is either not a top priority or they simply refuse to acknowledge the growing threat of the lone wolf phenomenon. Past behavior should be analyzed to see where the catalysts lie (Simeon, 2010).

\section{Reflections}

I knew the lone wolf was a reemerging phenomenon. I also knew that research was limited regarding the phenomenon and that most work pertaining to the lone wolf 
was discovered through organizational terrorism. My desire to explore and gain insight into the lone wolf terrorist while contributing to the body of literature was very motivational for me. Although I had a sampling methodology idea for the representativeness of the study, that idea changed when new themes and codes emerged during the analyzing process.

More research needs to be conducted on the phenomenon of lone wolf terrorism. This is not a once for all study on domestic lone wolf terrorism, but it does provide a practical framework for the mechanisms and processes that the lead individuals to be drawn to and/or away from a violent end. What this study does not do is provide relative case analysis within the design of the study. To get a better understanding of the domestic lone wolf, case analysis should be applied to this study explanation. The domestic lone wolf will continue to be a fanatic, as there will always be a need counter the threat.

\section{Limitations of the Study}

In chapter 1, I discussed the limitations of the study the term 'terrorism' itself. Terrorism is defined several ways and it depends on the personnel, agency, state, or country. I used RAND and the GTD definitions for the study; however, others define it differently. I used phenomenological design composing 177 incidents that took place in the U.S. post 9/11. These incidents may not give an accurate representation of acts in other countries. In addition, the results may not reflect beyond the individual's experience in the study or be comparable to other populaces of lone wolf terrorists. When looking at any large database of perpetrators, the conclusion is drawn from across society, age group, and even gender. Nonetheless, important insights can be gained from this 
literature. Future research should mirror previous studies, but different questions will likely garner different results using the same research method.

\section{Recommendations}

Research on lone wolf terrorists is sparse and group analysis is used to describe and reflect the lone wolf terrorist experience. I took the sparse data that was available and added to the collection of research. One recommendation I suggest is to continue secondary analysis of previous studies because there is pre-established levels of validity and reliability and the study was pre-designed. I caution profiling these individuals or creating typologies because there is no model that fits all perpetrators. Researching more into the extremisms and the subgroups of lone wolves could prove beneficial from their unique profiles. Lone wolves that have a mental illness should not be a sole indicator or viewed as a reduced threat. In the least, it should be looked upon as further value toward the comprehension of the lone wolf terrorist.

I recommend gaining access to a larger pool of perpetrators to obtain further diverse perspectives and experiences. The research that is currently available is unique and opportunities exist to advance value to this reemerging phenomenon. The process of radicalization and the perpetrators should continue to be a central focus. As the threat emerges, so will the different types of perpetrators and experiences of everyone (Pantucci, Ellis, \& Chaplais, 2016). Further research on Internet radicalization should be conducted because the role of the internet and how it guides individuals to carry out the act shows that it is a powerful tool for lone terrorist. Websites are virtual training rooms, 
offering numerous of things such as firing missiles, making bombs, and raising morale within oneself.

\section{Implications}

The findings could assist national security officials and intelligence agencies in identifying lone wolf individuals, weighing the actual threat versus the perception, developing better counterterrorism strategies for the lone wolf phenomenon, and enhancing relations with outside agencies. This is not just a national security problem, and all elements, locally and statewide, are needed to reduce the threat. Local and statewide officials are first responders and are in position to assist the government.

The literature implicates further research should be implemented around personal and political grievance, right-wing ideologies, and the significant indicators. Those who are grieving feel that an injustice has occurred to them or in society, and the grievance carries over into actions. This significant development could possibly lead to why other violent crimes are committed. Right-wing ideology findings further implicated that these individuals are more likely to commit domestic terrorist acts than Islamist or selfdeveloped terrorists. Focusing on right-wing subgroups could give a more accurate account than generalizing the concept of all right-wing groups.

No specific indicators can characterize the potential lone wolf terrorist. But things

like spontaneous communication, radical expressions, and being preoccupied by a cause or person could drive the point home. The act is intentional and the type of target lone wolves attack tells a story. However, judging a book by the cover leads to invalid analysis and invalid conclusions. The reality is that it is hard to quantify anything with 
lone wolf terrorism.

The three significant developments can set the stage for radical movements within lone wolf terrorist. The developments are large enough to include in the body of research, yet, precise enough to put into context detailed aspects on the lone wolf mechanisms and processes (Pajunen, 2013). Adopting extremist views is not just a Muslim’s prerogative; it can be anyone's prerogative as was demonstrated in the study. The intricate nature of these developments in the study reaffirms the compound process of being drawn to or away from violent ends. The reemergence of the domestic lone wolf will continue and merits further research. This study provides another framework for the radicalization process of the lone wolf.

\section{Implications for Social and Policy Change}

If national security official's focus on mental health or mental illness, the fear of lone wolves should be of no concern, on the other hand exaggerating the phenomenon may be. The problem is that the threat of lone wolves is creating a real impact, certainly calculated, by facilitating policy change in the United States, and burdening relationships causing a distrust between communities and law enforcement. The fear of Muslims is rising in the United States. Post 9/11 attacks against Muslim or their properties have increased.

The fundamental challenge of national security and politics is peril to our basic liberties. Right-wing ideological extremist are problems and causes of lone wolf terrorism in the United States. The fear of terrorism and Muslims has created more anti-immigrant politicians despite a low number of attacks from Islamist ideology extremist. A 
significant measure involves conformity: the less they grieve about injustices, the more likely they will be in accord to existing social standards, outlooks, and customs.

Having outside relations with other agencies and the community can reduce inspirations to act violently and promote cooperation across the board. The measures listed above, whether single-handedly or in grouping, do not prevent lone wolf acts. But it does make them more likely to be exposed in the process, less dangerous when not found and less efficient after an attack. They are critical for reducing lone wolf acts, which makes the phenomenon less probable and less perilous.

\section{Conclusion}

This study addressed the paradox between the considerable media attention lone wolf terrorism has received and the lack of sufficient examination attributed to the

phenomenon by exploring, identifying, and describing the mechanisms and processes that lead individuals to be drawn to or away from an existing radical movement and to act unilaterally and without direction toward violent ends. Downing and Mayer (2013) asserted that lone wolves are more dangerous than an established terrorist hierarchy, which lets them act upon a situation that plays out in their minds. These indicators are more than enough to pose a huge threat to national security based upon the mystique of the threat.

Findings for the central research question and sub questions revealed that there are three individual-level underlying mechanisms and processes (personal and political grievance, risk and status seeking, unfreezing), the phenomenon of the domestic lone wolf terrorist is not limited to a movement. Rather, lone terrorists operate on the fringes 
of extremist movements, with such loose associations being connected to right-wing ideologies, inspired and fascinated by Islamist ideologies of Arabian Peninsula and The Islamic State of Iraq (AQAP) and Levant (ISIL), and self-developed ideologies facilitating violence based on political, religious, or social change. The findings also suggest that gender, the internet, fixation, identification, and pseudo spontaneous communication are some of the indicators that characterize the potential lone wolf terrorist.

The purpose of this study was to focus on the phenomenon apart from other types of political violence and terrorism, using the RAND and GTD databases. Using the leaderless resistance theory, the bearing of this theory was found upon ideological inclusiveness that leaderless resistance advocates. Although leaderless resistance is used to shun detection, penetration, and execution by the government, ideological inclusiveness can be an advantage for individuals involved in groups (Joosse, 2007).

There is no winning with the American public. Countering domestic lone wolf terrorism is difficult and is easier said than done. My desire to gain insight into the perspectives of the lone wolf and having the ability to contribute to the body of literature was very motivational for me. While the research currently available is unique, opportunities exist to add value to this reemerging phenomenon. More importantly, the findings could assist national security officials and intelligence agencies in identifying lone wolf individuals, weighing the actual threat versus the perception, developing better counter strategies for the lone wolf phenomenon, and enhancing relations with outside agencies and the citizens of the United States. 


\section{References}

Acharya, U. D. (2013). War on terror or terror wars: The problem in defining terrorism. International Law \& Policy, 37, 653.

Agbiboa, D. (2013). The Nigerian burden: Religious identity, conflict and the current terrorism of Boko Haram. Conflict, Security \& Development, 13(1), 1-29. doi:10.1080/14678802.2013.770257

Albrecht, J. F. (2011). The NYPD success story: Crime reduction and narcotics enforcement. Pakistan Journal of Criminology, 3(2), 83-94.

Alexander, K. P. (2009). A review of Marc Sageman. Leaderless jihad: Terror networks in the twenty-first century. Terrorism \& Political Violence, 21(4), 639-642. doi:10.1080/09546550903256655

Alleged Fort Hood plotter thwarted by operational mistakes. (2011). Stratford Analysis, 84.

Altheide, D. L. (2006). Terrorism and the Politics of Fear. Cultural Studies? Critical Methodologies, 6(4), 415-439.

Andrews, J. (2009). The lone wolf killer. Counter Terrorist, 2(4), 6-12.

Anti-Defamation League (2013). Extremism in America. Retrieved from http://archive.adl.org/Learn/ext_us/Hoskins.asp?LEARN_Cat=Extremism\&LEA RN_Sub Cat=Extremism_in_America\&xpicked=2\&item $=$ Hoskins

Arndt, M. C. (2011). Leaderless jihad: Terror networks in the twenty-first century. Air and Space Power Journal, 25(4), 114-115. 
Asal, V. H., Ackerman, G. A., \& Rethemeyer, R (2012). Connections can be toxic: Terrorist organizational factors and the pursuit of CBRN weapons. Studies in Conflict \& Terrorism, 35(3), 229-254. doi:10.1080/1057610X.2012.648156

Bakker, E., \& De Graaf, B. (2010, November). Lone wolves. How to prevent this phenomenon? Expert Meeting Lone Wolves. The Hague, Netherlands: International Centre for Counter-Terrorism.

Bakker, E., \& De Graaf, B. (2011). Preventing lone wolf terrorism: Some CT approaches addressed. Perspectives on Terrorism, 5(5-6).

Bárcena-Martín, E., Imedio-Olmedo, L., \& Martín-Reyes, G. (2007). Inequality and deprivation within and between groups: An illustration of European Union countries. Journal of Economic Inequality, 5(3), 323-337. doi:10.1007/s10888-006-9046-4

Barnes, B. D. (2012). Confronting the one-man wolf pack: Adapting law enforcement and prosecution responses to the threat of lone wolf terrorism. Boston University Law Review, 92(1), 1614-1662.

Basibuyuk, O., Karakus, O., \& Akdogan, H. (2007). Fundamentalism as a universal mindset case study of religious fundamentalism: Turkish Hezbollah.

Understanding Terrorism: Analysis of Sociological \& Psychological Aspects, $22(1), 42-50$.

Bates, R. A. (2012). Dancing with wolves: Today's lone wolf terrorists. The Journal of Public and Professional Sociology, 4(1) 1-15.

Bergen, P., \& Hoffman, B. (2010). Assessing the terrorist threat: A report of the Bipartisan Policy Center's National Security Preparedness Group. Retrieved from 
http://bipartisanpolicy.org/sites/default/files/NSPG\%20Final\%20Threat\%20Asses sment.pdf

Beutel, A. J. (2007). Radicalization and homegrown terrorism in western Muslim communities: Lessons learned for America. Retrieved from http://www.minaret.org/MPAC\%20Backgrounder.pdf

Bjelopera, J. P. (2011). America jihadist terrorism: Combating a complex threat. International Journal of Terrorism \& Political Hot Spots, 6(3), 339-476.

Bjelopera, J. P. (2012). The domestic terrorist threat: Background and issues for Congress. Congressional Research Service: Report, 1-66.

Boaz, G. (2010). Defining terrorism: Is one man's terrorist another man's freedom fighter? Police Practice and Research, 3(4), 287-304.

Boslaugh, S. (2007). Secondary data sources for public health: A practical guide. New York, NY: Cambridge.

Breckenridge, J. N., Zimbardo, P. G., \& Sweeton, J. L. (2010). After years of media coverage, can one more video report trigger heuristic judgments? A national study of American terrorism risk perceptions. Behavioral Sciences of Terrorism \&

Brooks, R. A. (2011). Muslim "homegrown" terrorism in the United States: how serious is the threat? International Security, 36(2), 7-47.Political Aggression, 2(3), 163 178. doi:10.1080/19434471003768826

Boslaugh, S. (2007). Secondary data for public health: A practical guide. Cambridge University Press. 
Bryneilson, J., Horndahl, A., Johansson, F., Katti, L., Martenson, C., \& Svenson, P. (2013). Harvesting and analysis of weak signals for detecting lone wolf terrorist. Security Informatics, 2(11).

Bryneilson, J., Horndahl, A., Johansson, F., Katti, L., Martenson, C., \& Svenson, P. (2013). Harvesting and analysis of weak signals for detecting lone wolf terrorist. Security Informatics, 2(11).

Carafano, J (2011). After Oslo: Lessons for the United States. Washington, DC: Heritage Foundation. Retrieved from http://www.heritage.org/research/reports/2011/07after-oslo-attacks-lessons-forthe-united-states

Chermak, S., Freilich, J., \& Suttmoeller, M. (2013). The organizational dynamics of farright hate groups in the United States: Comparing violent to nonviolent organizations. Studies in Conflict \& Terrorism, 36(3), 193-218. doi:10.1080/1057610X.2013.755912

Christensen, C. (2004). Political victims and media focus: The killings of Laurent Kabila, Zoran Djindjic, Anna Lindh, and Pim Fortuyn. Journal for Crime, Conflict, and Media, 1(1), 23-69.

The Central Intelligence Agency (2013). Organization Definitions of Terrorism. Retrieved from www. Secbrief.org

Creswell, J.W. (2009). Research design: Qualitative, quantitative, and mixed methods approaches. Thousand Oaks, CA: Sage Publications. 
Coffey, K. (2011). The Lone Wolf-Solo Terrorism and the Challenge of Preventative Prosecution. Fiu L. Rev., 7, 1.

Coaffee, J., \& Rogers, P. (2008). Rebordering the city for new security challenges: from counter-terrorism to community resilience. Space and Polity, 12(1), 101-118.

Coffey, S. (2011). The case for the creation of a global FBI. Central European Journal of International \& Security Studies, 5(2), 23-56.

Cooper, R. (2012). From big lies to the lone wolf: How social networking incubates and multiplies online hate and terrorism. In The Changing Forms of Incitement to Terrorand Violence: The Need for a New International Response. Retrieved from http://jcpa.org/wp-content/uploads/2012/11/INCITEMENT_TO_TERROR_4.pdf.

Cox, D. G. (2009). Leaderless jihad: Terror networks in the twenty-first century. Parameters: U.S. Army War College, 39(3), 127-129.

Dale, C. (2013, August). National Security Strategy: Mandates, Execution to Date, and Issues for Congress. LIBRARY OF CONGRESS WASHINGTON DC CONGRESSIONAL RESEARCH SERVICE.

Dean, G., Bell, P., \& Newman, J. (2012). The dark side of social media: Review of online terrorism. Pakistan Journal of Criminology, 3(3), 107-126.

DeRosa, M. (2005). Section 206. Roving Surveillance Authority under FISA. Retrieved from www.Apps.Americanbar.org DiRienzo, C., \& Das, J. (2012). Terrorist risk and income revisited. Behavioral Sciences of Terrorism \& Political Aggression, 4(3), 175. doi:10.1080/19434472.2011.565569 
Downing, M., \& Mayer, M. (2013). Preventing the next lone wolf terrorist attack requires stronger federal and state and local capabilities. Retrieved from http://www.heritage.org/research/reports/2013/06/preventing-the-next-lone-wolfterrorist-attack-requires-stronger-federalstatelocal-capabilities

Eren, S. (2007). Psychology and the mindset of suicide bombers. Suicide as a Weapon, $30(1), 28-37$.

Federal Bureau of Investigation (2013). Operation lone wolf. Retrieved from http://www.fbi.gov/sandiego/about-us/history/operation-lone-wolf

Feldman, M. (2013). Comparative lone wolf terrorism: Toward a heuristic definition. Democracy and security, 9(3), 270-286.

Friedman, B. H., Harper, J., \& Preble, C. A. (2010). Terrorizing Ourselves: Why US Counterterrorism Policy is Failing and How to Fix It. Cato Institute.

Gartenstein-Ross, D. (2009). Leaderless Jihad: Terror networks in the twenty-first century. Middle East Quarterly, 16(3), 92-93.

Gilly, T. (2013). The new paradigm: Terrorism policing is more than policing terrorists. The need for adaptive models of terrorism policing. Homeland Security Review, $7(2), 179-226$.

Glaser, J., \& Laudel, G. (2013). Life with and without coding: Two methods for earlystage data analysis in qualitative research aiming at causal explanations. In Forum/Qualitative Sozialforschung/Forum: Qualitative Social Research, (14)2. 
Gray, P. W. (2013). Leaderless resistance, networked organization, and ideological hegemony. Terrorism and Political Violence, 25(5), 655-671.

Greenwald, G. (2014). No place to hide: Edward Snowden, the NSA, and the US surveillance state. Macmillan.

Gruenewald, J., Chermak, S., \& Freilich, J. D. (2013). Overview of: Distinguishing loner attacks from other domestic extremist violence: A comparison of rar-right homicide incident and offender characteristics. Criminology \& Public Policy, 12(1), 63-64. doi:10.1111/1745-9133.12009

Guterman, K. (2013). The Dynamics of Stereotyping: Is a new image of the terrorist evolving in American popular culture? Terrorism \& Political Violence, 25(4), 640-652. doi:10.1080/09546553.2013.814506

Hearing on Boston bombings points to lapses in information sharing by feds, Value of grant funding (2013). Defense Daily International, 6.

Herschinger, E. (2013). A battlefield of meanings: The struggle for identity in the UN debates on a definition of international terrorism. Terrorism \& Political Violence, 25(2), 183-201. doi:10.1080/09546553.2011.652318

Hoffman, B. (2013). RAND corporations. Countering the new terrorism. Retrieved from http://www.rand.org/pubs/monograph_reports/MR989.html

Howie, L. (2012). Media and Terrorism: Global Perspectives.

Horne, C. (2012). Methodological triangulation in the analysis of terrorist networks. Studies In Conflict \& Terrorism, 35(2), 182-192. 
Hua, J., \& Bapna, S. (2012). How can we deter cyber terrorism? Information Security

Journal: A Global Perspective, 21(2), 102-114. doi:10.1080/19393555.2011.647250

International Association of Chiefs of Police (2012). Rarely does an individual commit ideologically-motivated acts of violence in complete isolation, without having been influenced, directed, guided, or assisted by other violent extremists.

Retrieved from http://www.theiacp.org/portals/0/pdfs/IACP COT_LoneTerrorists__FINALAug12.pdf

Joosse, P. (2007). Leaderless resistance and ideological inclusion: The case of the Earth Liberation Front. Terrorism \& Political Violence, 19(3), 351-368. doi:10.1080/09546550701424042

Kassel, W. (2009). Terrorism and the international anarchist movement of the late nineteenth and early twentieth centuries. Studies in Conflict \& Terrorism, 32(3), 237-252. doi:10.1080/10576100802671009

King, M., \& Taylor, D. M. (2011). The radicalization of homegrown jihadists: A review of theoretical models and social psychological evidence. Terrorism \& Political Violence, 23(4), 602-622. doi:10.1080/09546553.2011.587064

Klein, J. J. (2012). Deterring and dissuading nuclear terrorism. Journal of Strategic Security, 5(1), 15-29. doi:10.5038/1944-0472.5.1.2

Kouri, J. (2011). Lone wolf terrorist threat increasing, say security experts. Retrieved from http://www.aim.org/guest-column/lone-wolf-terrorist-threat-increasing-saysecurity-experts/ 
Lachlan, K. A., Spence, P. R., \& Seeger, M. (2009). Terrorist attacks and uncertainty reduction: Media use after September 11. Behavioral Sciences of Terrorism \& Political Aggression, 1(2), 101-110. doi:10.1080/19434470902771683

Lammers, C. J., \& Hickson, D. (Eds.). (2013). Organizations Alike and Unlike (rle: Organizations): International and Inter-institutional Studies in the Sociology of Organizations (Vol. 17). Routledge.

Lasky, S. (2012). Al-Qaeda may be dead, but the lone wolf threat remains. Security Technology Executive, 22(4), 6.

Lemieux, F., \& Regens, J. L. (2012). Assessing terrorist risks: Developing an algorithmbased model for law enforcement. Pakistan Journal of Criminology, 3(3), 33-50.

Levitt, M. (2017). Low cost, High Impact: Combating the Financing of Lone-Wolf and Small Scale Terrorist Attacks. Retrieved from www.financialservices.house.gov

Lieber, K. A., \& Press, D. G (2013). Why states won’t give nuclear weapons to terrorists. International Security, 38(1), 80-104.

Lieberman, J., \& Collins, S. (2011). A ticking time bomb. Hearing before the Committee on Armed Services, United States Senate, Washington, DC. Retrieved from http://www.gpo.gov/fdsys/pkg/CHRG-111shrg63686/pdf/CHRG111shrg63686.pdf

Lindsay, B. R. (2011). Social media and disasters: Current uses, future options, and policy considerations.

Lui, E. (2011). Congressional Research Service. Amendments to the Foreign Intelligence Surveillance Act. Retrieved from http://www.fas.org/sgp/crs/intel/R40138.pdf 
Margulies, P. (2013). The NSA in Global Perspective: Surveillance, Human Rights, and International Counterterrorism. Fordham L. Rev., 82, 2137.

Marshall, C., \& Rossman, G. B. (2014). Designing Qualitative Research. Sage Publications.

Martinez, J. (2012). Terrorist attacks on American soil: From the Civil War era to the present. Lanham, MD: Bowman \& Littlefield Publications.

Mauroni, A. (2013). Facing our fears, managing the threat. U.S. Naval Institute Proceedings, 139(10), 36-41.

Mazhar, M., Khan, S., \& Goraya, N. S. (2013). Understanding terrorism and the ways to root out: Perceptions and realities. Journal of Political Studies, 20(1), 67-82.

McCauley, C., Moskalenko, S., and Van Son, B. (2013). Characteristics of lone-wolf violent offenders: A comparison of assassins and school attackers. Perspectives on Terrorism, 7(1). Retrieved from http://www.terrorismanalysts.com/pt/index.php/pot/article/view/240/html

McComb, J. M. (2013). Closing Pandora's Box: The threat of terrorist use of weapons of mass destruction. Global Security Studies, 4(1), 71-92.

McClure, J. (2013). Has Hamas’ progressive terrorism tactics evolved past traditional counterterrorism measures? An analysis of a means to an end for the terrorist organization hamas. Global Security Studies, 4(1), 31-37.

McNabb, D.E (2010) Research methods in public adminstration and nonprofit management: quantitative and qualitative approaches $\left(3^{\mathrm{rd}} \mathrm{ed}\right)$. Armonk, NY: M.E. Sharpe, Inc 
Meisels, T. (2009). Defining terrorism-A typology. Critical Review of International Social and Political Philosophy, 12(3), 331-351.

Mendelson, M. E. (2008). A systems understanding of terrorism with implications for policy (Doctoral Dissertation). Retrieved from ProQuest Dissertations and Theses, 658. http://search.proquest.com/docview/304682845? accountid=14872.

Merari, A., Diamant, I., Bibi, A., Broshi, Y., \& Zakin, G. (2010). Personality characteristics of self-martyrs/suicide bombers and/organizers of suicide attacks. Terrorism \& Political Violence, 22(1), 87-101. doi:10.1080/09546550903409312 Michael, G. (2012). Leaderless resistance: The new face of terrorism. Defence Studies, 12(2), 257-282. doi:10.1080/14702436.2012.699724

Michael, G. (2013). The new media and the rise of exhortatory terrorism. Strategic Studies Quarterly, 7(1), 40-68.

Moses, T. (2010). Being treated differently: Stigma experiences with family, peers, and school staff among adolescents with mental health disorders. Social science \& medicine, 70(7), 985-993.

Miller, P. D. (2013). The Contemporary Presidency: Organizing the National Security Council: I Like Ike's. Presidential Studies Quarterly, 43(3), 592-606.

Mueller, R. (2003). War on terrorism. Testimony before the Select Committee on Intelligence of the United States Senate, Washington, DC. Retrieved from https://www.fas.org/irp/congress/2003_hr/021103mueller.html.

Napolitano, J. (2011). Understand the Homeland Threat Landscape-Considerations for the 112th Congress. Testimony before the House Committee on Homeland 
Security, Washington DC. Retrieved from http://www.gpo.gov/fdsys/pkg/CHRG112hhrg72212/pdf/CHRG-112hhrg72212.pdf

National Alliance (2011). Background Information Summaries, 18.

National Consortium for the Study of Terrorism and Responses to Terrorism (START). (2016). Global Terrorism Database. Retrieved from https://www.start.umd.edu/gtd

Nijboer, M. (2012). A review of lone wolf terrorism: The need for a different approach. Social Cosmo, 3(1), 33-39.

Northern Arizona University (2013). Methods of data collections. Retrieved from http://www.prm.nau.edu/prm447/methods_of_data_collection_lesson.htm

O’Donnell, B., \& Gray, D. H. (2012). Media and state sponsored terrorism. Global Security Studies, 3(2), 43-55.

Painter, W. L. (2013). Issues in homeland security policy for the 113th Congress.

Pajunen, C. The Lone Wolf Terrorist: Mechanisms and Triggers of a Process-Driven Radicalization. Retrieved from http://www.ir-ia.com/reports/IRIA-Report-GlobalTerrorism-Trend-4.pdf

Pantucci, R. (2011). What have we learned about lone wolves from Anders Behring Breivik? Perspectives on Terrorism, 5(5/6), 27-42.

Pantucci, R., Ellis, C., \& Chaplais, L. (2016). Lone actor terrorism.

Phillips, P. J. (2011). Lone wolf terrorism. Peace Economics, Peace Science, \& Public Policy, 17(1), 1-29. 
Perlmutter, D. (2013). Prelude to the Boston bombings. Middle East Quarterly, 20(4), 6777.

Pfeiffer, C. P. (2012). Terrorism and its oxygen: A game-theoretic perspective on terrorism and the media. Behavioral Sciences of Terrorism \& Political Aggression, 4(3), 212-228. doi:10.1080/19434472.2011.594629

Political Research Associates (2013). Researching the right for progressive change makers. Retrieved from http://www.publiceye.org/liberty/terrorism/insurgency/leaderless-resistance.html

Preble, C. (2011). Understanding the dimensions, and limits, of American power. World Politics Review (19446284), 4.

Rapin, A. (2011). What is terrorism? Behavioral Sciences of Terrorism \& Political Aggression, 3(3), 161-175. doi:10.1080/19434472.2010.512155

RAND Database of Worldwide Terrorism Incidents (2013). A RAND National Defense Research Institute project. Retrieved from http://www.rand.org/nsrd/projects/terrorms-incidents.html

Rasler, K., \& Thompson, W. R. (2009). Looking for waves of terrorism. Terrorism \& Political Violence, 21(1), 28-41. doi:10.1080/09546550802544425

Research Methods Knowledge Database (2013). Qualitative approaches. Retrieved from http://www.socialresearchmethods.net/kb/qualapp.php

Ritchey, D. (2013). The Power of Partnerships. Security: Solutions for Enterprise Security Leaders, 50(8), 16-22. 
Rollins, J., \& Wilson, C. (2007). Terrorist capabilities for cyber attack: Overview and policy issues. Retrieved from http://italy.usembassy.gov/ pdf/other/RL33123.pdf

Sagers Herzog, C. (2013). Lone wolf terrorism: Understanding the growing threat. Diplomatic Courier, 7(4), 64.

Said, B. (2012). Hymns nasheeds: A contribution to the study of the jihadist culture. Studies in Conflict \& Terrorism, 35(12), 863-879. doi:10.1080/1057610X.2012.720242

Sauter, M., \& Carafano, J. (2012). Homeland Security: A Complete Guide 2/E. McGraw Hill Professional.

Sedgwick, M. (2012). Jihadist ideology, Western counter-ideology, and the ABC model. Critical Studies on Terrorism, 5(3), 359-372. doi:10.1080/17539153.2012.723520

Shea, D. A. (2013). Chemical agents as weapons of terror rather than as weapons of mass destruction. Congressional Research Service: Report, 11-12.

Shoshani, A., \& Slone, M. (2008). The drama of media coverage of terrorism: Emotional and attitudinal impact on the audience. Studies in Conflict \& Terrorism, 31(7), 627-640. doi:10.1080/10576100802144064

Silverman, D. (ED). (2016). Qualitative Rearch. Sage.

Simeon, J. C. (2010). Complicity and culpability and the exclusion of terrorists from convention refugee status post-9/11. Refugee Survey Quarterly, 29(4), 104137.doi:10.1093/rsq/hdq036

Small, M.L. (2009). How many cases do I need? On science and the logic of case selection in field-base research. Ethnography, 10(10, 5-38 
Spaaij, R. (2010). The enigma of lone wolf terrorism: An assessment.

Studies in Conflict \& Terrorism, 33(9), 854-870.

Sonoma University (2013). Lecture on Phenomenology. Retrieved from http://www.sonoma.edu/users/d/daniels/phenomlect.html

Spencer, A. (2006). Questioning the concept of 'New Terrorism'. Peace, Conflict and Development, 1-33.

Sringernyuang, L. (ND). Ethical issues in documentary and secondary analysis. Retrieved from http://muirb.mahidol.ac.th/ref9/train/230355/powerpoint_\%E0\%B8\%AD_\%E0\%B8\%A5\% E0\%B8\%B7\%E0\%B8\%AD\%E0\%B8\%8A\%E0\%B8\%B1\%E0\%B8\%A2.pdf

Stampnitzky, L. (2013). Disciplining Terror: How Experts Invented'Terrorism'. Cambridge University Press.

Stewart, S. (2011a). Oslo, Norway: Lessons learned from a successful lone-wolf attack. Police one. Retrieved from http://www.policeone.com/terrorism/articles/4146174-Oslo-NorwayLessonslearned-from-a-successful-lone-wolf-attack/.

Stewart, S. (2011b). Cutting though the lone-wolf hype. Retrieved from http://www.stratfor.com/weekly/20110921-cutting-through-lone-wolf-hype

Stump, J. L. (2013). On the future of critical terrorism studies: A response to Richard Jackson's minimal foundationalist redefinition of terrorism. Behavioral Sciences 
of Terrorism \& Political Aggression, 5(3), 217-224.

doi:10.1080/19434472.2011.629579

Sunstein, C. R. (2008). Misery and company. New Republic, 239(7), 39-43.

Teich, S. (2013). Trends and developments in lone wolf terrorism in the western world.

Retrieved from

http://www.ict.org.il/Articles/tabid/66/Articlsid/1234/currentpage/1/Default.aspx

The University of Buffalo (2013). The legal aftermath of the assassination of William McKinley. Retrieved from http://library.buffalo.edu/pan-am/exposition/law/

South Alabama University. Twelve major characteristics of a qualitative study. Retrieved from http://www.southalabama.edu/coe/bset/johnson/lectures/lec12.htm

Tikuisis, P. (2009). On the relationship between weak states and terrorism. Behavioral Sciences of Terrorism \& Political Aggression, 1(1), 66-79.

doi:10.1080/19434470802482175

Transnational Terrorism, Security, and the Rule of Law (2008). Radicalization, recruitment, and the EU counter-radicalization strategy. Brussels: European Commission Sixth Framework Program.

Tucker, D. (2010). Jihad dramatically transformed? Sageman on jihad and the internet. Homeland Security Affairs, 6(1), 1-7.

Turchie, T., \& Puckett, K. (2007). Hunting the American terrorist: The FBI's war on homegrown terror. Palisades, NY: History Publishing.

Unites States., \& Obama, R. (2013). National security strategy of the United States: the Whitehouse. 
University of Connecticut (2013). NVivo. SLG software licensing group. Retrieved from http://software.uconn.edu/software/software_detail.php?softid=nvivo

Valentin-Bogdan, D. Ă. N. I. L. Ă. (2013). RISKS AND THREATS RECOGNIZED IN THE SECURITY ENVIRONMENT. Scientific Research \& Education in the Air Force-AFASES, 1.

Vartanian, T.P. (2011). Secondary data analysis. New York, NY: Oxford

Van Gelder, J. (2013). Beyond rational choice: The hot/cool perspective of criminal decision making. Psychology, Crime \& Law, 19(9), 745-763. doi:10.1080/1068316X.2012.660153

Victoroff, J., Adelamn, J., \& Stern, N. (2006). Sympathy for terrorism: Possible interaction between social, emotional, and neuroendocrine risk factors. Tangled Roots: Social \& Psychological Factors in The Genesis of Terrorism, 11(1), 227234.

Waugh, M. H. (2006). Understand terror networks. Journal of Police Crisis Negotiations, 6(1), 137-139. doi:10.1300/J173v06n01_10

White, S. I. (2010). Moving from mindset to outcome. Journal of Counterterrorism \& Homeland Security International, 16(3), 48-51 
Appendix A: Central Research Question and Subquestions

Central research question: What are the underlying mechanisms and processes that lead individuals to be drawn to or away from an existing radical movement and to act unilaterally and without direction to violent ends?

Theme: In brief, the three individual-level underlying mechanisms and processes that lead individuals to be drawn to or away from an existing radical movement and to act unilaterally and without direction to violent ends are: Personal and political grievances, Risk and status seeking, and unfreezing.

Sub question 1: What causes an individual to participate in lone wolf terrorism?

Theme: First, the phenomenon of the domestic lone wolf terrorist is not limited in extent to a particular type of movement. Rather lone terrorist operate on the fringes of extremist movements, with such loose associations being connected to right-wing ideologies, inspired and fascinated by Islamic ideologies of Arabian Peninsula and The Islamic State of Iraq (AQAP) and Levant (ISIL), and self-developed ideologies facilitating violence based on political, religious, or social change.

Sub question 2: Are there consistent and significant indicators that can characterize a potential lone wolf actor?

Theme: In characterizing the lone wolf terrorist, there are several indicators: gender, internet, radical expressions, pseudo spontaneous communication, and identification. 
Appendix B: Terms and Defintions

Al Qaida in the Arabian Peninsula- is a militant Islamist organization.

Anarchists- generally oppose "illegitimate authority".

$\underline{\text { Animal Liberation Front- is an international, clandestine leaderless resistance that }}$ engages in direct action in pursuit of animal rights.

Anti-abortion extremists- individuals or groups who believe abortion is unethical and that violence is justified against people and establishments providing abortion services. Anti-government extremists- refer to any fringe movement with an antipathy towards government.

Anti-gun control extremists- individuals that see any restriction on the manufacture, ownership, or use of firearms infringes this sacred right.

Anti-Israeli- against Israel.

Anti-Kim Jong- against King Jong.

Anti-liberal Extremists- believe the United States of America is a Christian country that its people are Christian, and that government reflect its beliefs and values and oppose all effort to deny or weaken Christian heritage.

Anti-Muslim Extremists- the threat of infiltration of Sharia, or Islamic law, into the U.S. court systems.

Anti-Police Extremists- opposed to or against the police.

Anti-Semitic- refers to hostile or prejudice against Jews because of their religion and/or ethnicity. 
Anti-Sikh Extremists- individuals who mistaken Sikhism's for Islam and believes violence is justified

Anti-Trump Extremists- against President Trump.

Anti-white Extremists- against white supremacy.

Courtroom Extremists- against the court system.

Earth Liberation Front- uses "economic" sabotage and guerilla warfare to stop the destruction of the environment.

Fixation- obsessed with a person or cause.

Gender- Male or Female

Identification- willingness of the attacker to commit violence as an agent of a particular belief system.

Internet- makes it easier for would be lone wolf terrorist to uncover ideologies and associations supporting their belief systems, and for them to share their intentions and actions with via social media.

Jihadi-inspired extremists- refer to Islamic extremism occurring within the United States.

Minuteman American Defense-is a volunteer group headed by Chris Simox and dedicated to preventing illegal crossings of the United States border.

Muslim extremist- any form of Islam that opposes "democracy", the rule of law, individual liberty and mutual respect and tolerance of different faiths and beliefs. NEO-Nazi-extremists- share a hatred for Jews and love for Adolf Hitler. 
Personal and Political grievance- Individual radicalization usually occurs with a blending of personal and group grievance, a blending in which personal grievance means hostility or negative identification with a group seen as perpetrators of injustice, and group grievance means positive identification with a group seen as the victims of injustice.

ProLGBT- extremists- Those who promote homosexuality and same sex marriage. $\underline{\text { Pseudo spontaneous communication-involves the intentional and strategic }}$ manipulation of some formal displays.

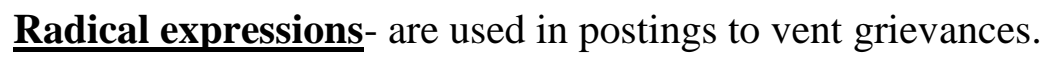

Right-wing extremists- encompass individuals or groups associated with white supremacist, anti-government, sovereign citizen, militia, or other ideologies that target specific religious, ethnic, or other minority groups.

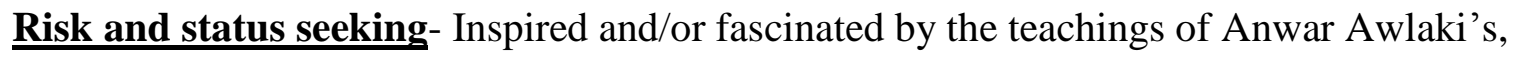
Abu Muhammad al Adnani, and or Osama bin Laden under Al'Qaida in the Arabian Peninsula or The Islamic State of Iraq and Levant (ISIL) for whom violence may seem the best path respect.

Soveign Citizens- is a loose grouping of American litigants, commentators, tax protesters, and financial-scheme promoters.

Unfreezing- Unfreezing is a personal crisis such as a mental disorder or illness in disconnection that leaves an individual with less to lose and in search of new directions White extremists- the belief that white people are superior to those of all other races. Tehrik-i-Taliban (TTP) - is a force multiplier of Al Qaida. 
Unknown- bleak to no identity at all.

Veterans for non-religious memorials- individuals or groups that will stop at nothing to intimidate communities to tear down veterans memorials. 
Appendix C: NIH Certification

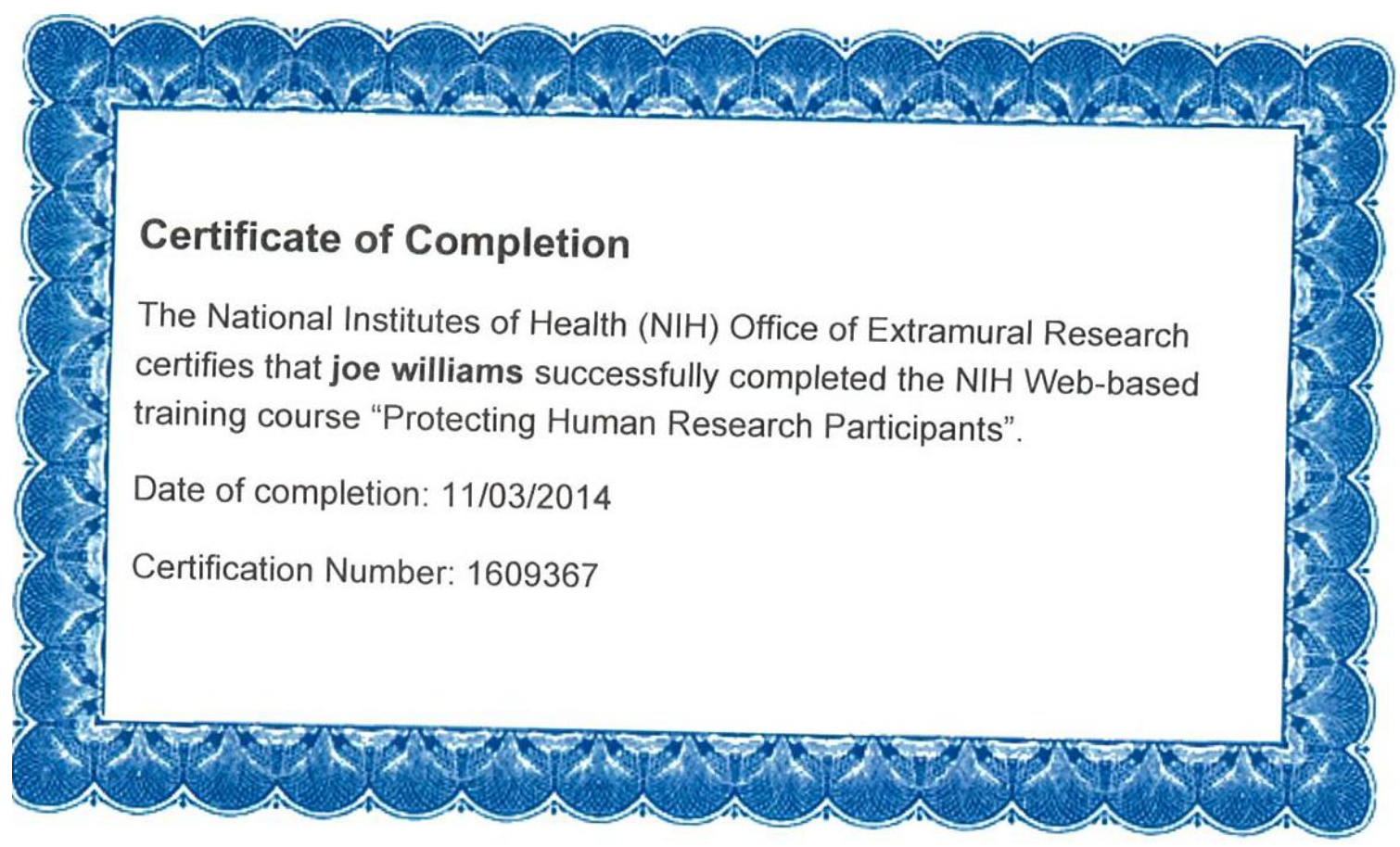


Appendix D: IRB Materials Approved

Dear Mr. Williams,

This email is to notify you that the Institutional Review Board (IRB) confirms that your doctoral capstone entitled, "Leaderless Resistance: The Manifestation of Lone Wolves in the U.S." meets Walden University's ethical standards. Since this project will serve as a Walden doctoral capstone, the Walden IRB will oversee your capstone data analysis and results reporting. Your IRB approval number is 06-13-17-0307965.

This confirmation is contingent upon your adherence to the exact procedures described in the final version of the documents that have been submitted to IRB@ mail.waldenu.edu as of this date. This includes maintaining your current status with the university and the oversight relationship is only valid while you are an actively enrolled student at Walden University. If you need to take a leave of absence or are otherwise unable to remain actively enrolled, this is suspended.

If you need to make any changes to the project staff or procedures, you must obtain IRB approval by submitting the IRB Request for Change in Procedures Form. You will receive confirmation with a status update of the request within 10 business days of submitting the change request form and are not permitted to implement changes prior to receiving approval. Please note that Walden University does not accept responsibility or liability for research activities conducted without the IRB's approval, and the University will not accept or grant credit for student work that fails to comply with the policies and procedures related to ethical standards in research. 
When you submitted your IRB materials, you made a commitment to communicate both discrete adverse events and general problems to the IRB within 1 week of their occurrence/realization. Failure to do so may result in invalidation of data, loss of academic credit, and/or loss of legal protections otherwise available to the researcher. Both the Adverse Event Reporting form and Request for Change in Procedures form can be obtained at the IRB section of the Walden website:

http://academicguides.waldenu.edu/researchcenter/orec

You are expected to keep detailed records of your capstone activities for the same period of time you retain the original data. If, in the future, you require copies of the originally submitted IRB materials, you may request them from Institutional Review Board. Both students and faculty are invited to provide feedback on this IRB experience at the link below: http://www.surveymonkey.com/s.aspx?sm=qHBJzkJMUx43pZegKlmdiQ_3d_3d

Sincerely,

Libby Munson

Research Ethics Support Specialist

Office of Research Ethics and Compliance

Walden University

100 Washington Avenue South, Suite 900

Minneapolis, MN 55401

Email: irb@mail.waldenu.edu

Phone: (612) 312-1283 
Fax: (626) 605-0472

Information about the Walden University Institutional Review Board, including instructions for application, may be found at this link:

http://academicguides.waldenu.edu/researchcenter/orec 